\title{
Active faults and historical earthquakes in the Messina Straits area (Ionian Sea)
}

\author{
A. Polonia ${ }^{1}$, L. Torelli ${ }^{2}$, L. Gasperini ${ }^{1}$, and P. Mussoni ${ }^{2}$ \\ ${ }^{1}$ Institute of Marine Sciences CNR ISMAR-Bo, Via Gobetti, 101, 40129 Bologna, Italy \\ ${ }^{2}$ University of Parma, Dip. Scienze della Terra, Parco Area delle Scienze, 157/A Parma, Italy \\ Correspondence to: A. Polonia (alina.polonia@ismar.cnr.it) \\ Received: 30 September 2011 - Revised: 30 April 2012 - Accepted: 10 May 2012 - Published: 24 July 2012
}

\begin{abstract}
The Calabrian Arc (CA) subduction complex is located at the toe of the Eurasian Plate in the Ionian Sea, where sediments resting on the lower plate have been scraped off and piled up in the accretionary wedge due to the African/Eurasian plate convergence and back arc extension. The CA has been struck repeatedly by destructive historical earthquakes, but knowledge of active faults and source parameters is relatively poor, particularly for seismogenic structures extending offshore. We analysed the fine structure of major tectonic features likely to have been sources of past earthquakes: (i) the NNW-SSE trending Malta STEP (Slab Transfer Edge Propagator) fault system, representing a lateral tear of the subduction system; (ii) the out-of-sequence thrusts (splay faults) at the rear of the salt-bearing Messinian accretionary wedge; and (iii) the Messina Straits fault system, part of the wide deformation zone separating the western and eastern lobes of the accretionary wedge.

Our findings have implications for seismic hazard in southern Italy, as we compile an inventory of first order active faults that may have produced past seismic events such as the 1908, 1693 and 1169 earthquakes. These faults are likely to be source regions for future large magnitude events as they are long, deep and bound sectors of the margin characterized by different deformation and coupling rates on the plate interface.
\end{abstract}

\section{Introduction}

The convergence between the African and Eurasian Plates has generated a $10-\mathrm{km}$ thick accretionary wedge in the Calabrian Arc (CA) subduction complex due to offscraping of the thick sedimentary section resting on the lower African
Plate. The overall geometry of the subduction complex (i.e. depth of the basal detachment, geometry and structural style of different tectonic domains), as well as the location and geometry of major faults, has been reconstructed through an analysis of geophysical data at different scales (Polonia et al., 2011). The complex structure of the subduction complex reflects convergence in a pre-collisional stage, where the African Plate oceanic crust had already been consumed, except in the Ionian Sea abyssal plain. Different rates of collision between the continental blocks result in the irregular plate boundary and segmentation of the subduction complex. In this complex tectonic setting, active deformation has been described in different sectors of the subduction complex: both at the outer deformation front and in the inner portions of the accretionary wedge, where shortening is accommodated along out-of-sequence thrusts. Active transfer structures segment longitudinally the subduction complex and accommodate differential movements between crustal blocks.

Active deformation is reflected in the high seismicity of this area. The CA subduction complex, in fact, is part of the most active seismic belt of the central Mediterranean region; it faces the highly populated regions of southern Italy, which were struck repeatedly by large magnitude earthquakes in the recent past (Bottari et al., 1989; Jacques et al., 2001; Galli and Bosi, 2003; Gutscher et al., 2006; Jenny et al., 2006), often associated with destructive tsunamis (Piatanesi and Tinti, 1998; Tinti et al., 2004). For several major earthquakes in the region, like the 1908 (Mulargia and Boschi, 1983; Bottari et al., 1986; Capuano et al., 1988; De Natale and Pingue, 1991; Amoruso et al., 2002; Pino et al., 2009) and 1693 (Bianca et al., 1999; Sirovich and Pettenati, 1999; Monaco and Tortorici, 2000; Gutscher et al., 2006), it has 


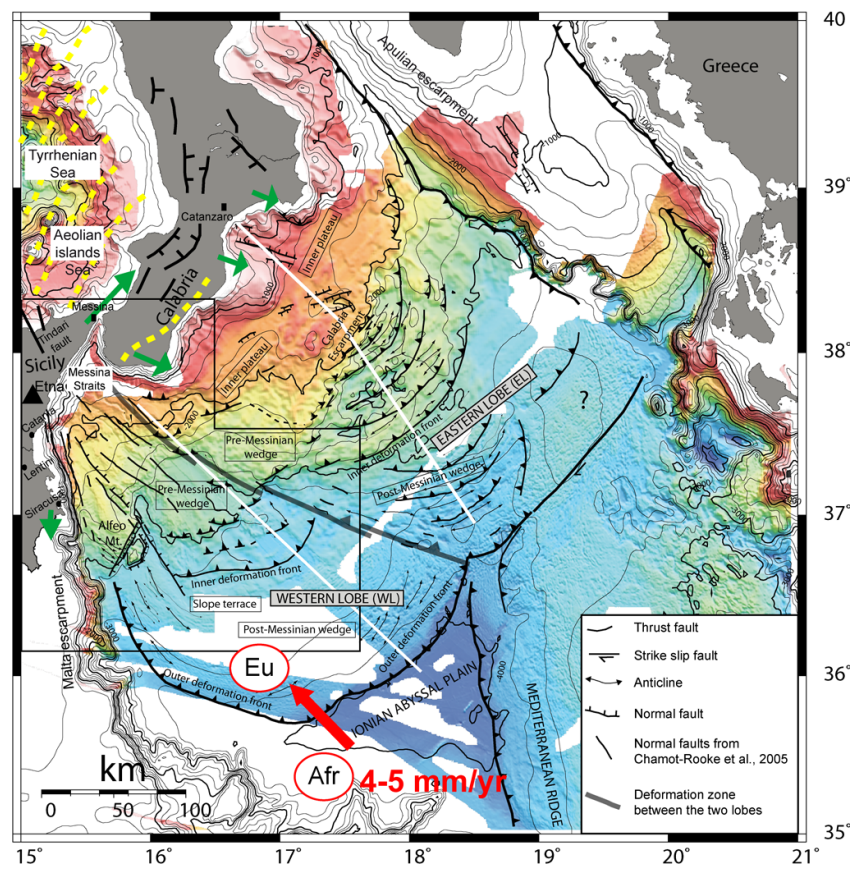

Fig. 1. Geodynamic setting of the study area. The tectonic model is modified from Polonia et al. (2011). Slip vector in the African reference frame is indicated by a red arrow. In green are GPS vectors in the Apulian-fixed reference frame in which the motion of Calabria is parallel to the slip vector, suggesting the existence of active crustal compression as a result of subduction of the Ionian lithosphere beneath the Calabrian Arc (D'Agostino et al., 2008). The NW ward dipping subducting slab of the African Plate is represented by the yellow isodepth lines in the Tyrrhenian Sea spacing from 100 to $450 \mathrm{~km}$ depth (Selvaggi and Chiarabba, 1995). Eu: Europe, Afr: Africa. The inset box represent the working area shown also in Fig. 3 while white lines represent MCS profiles shown in Fig. 2.

been suggested that seismogenic structures may have been entirely or partially located offshore.

To address the seismogenic behaviour of the CA region and evaluate its seismogenic/tsunamigenic potential, it is essential to unravel the tectonic setting of the submerged portion of the system, reconstruct the fine-scale geometry of single fault strands and relate their kinematics to the overall geodynamic framework of the central Mediterranean. During a recent cruise with $\mathrm{R} / \mathrm{V}$ Urania, part of the CALAMARE project (CALabrian Arc MARine geophysical Experiment), we acquired geophysical data at different scales that were analysed together with data collected in the last decades to address the fine structure of the main active faults in the western CA, south of the Messina Straits (Fig. 1). In this paper, we propose an inventory of tectonic features as a possible cause of past large magnitude earthquakes in the area.

\subsection{Geological setting}

The CA (Fig. 1) is located above a 300-km-wide subduction zone dipping toward NW, characterized by an active volcanic arc (the Aeolian Islands), a back-arc basin (Tyrrhenian Sea) and a well defined Wadati-Benioff zone (Wortel and Spakman, 2000), with earthquakes descending to nearly $500 \mathrm{~km}$ depth (Selvaggi and Chiarabba, 1995).

The present day tectonic configuration of the subduction system was reached after $1-0.7 \mathrm{Ma}$, when the plate boundary system reorganized to accommodate the Africa-Eurasia convergence (Goes et al., 2004; Billi et al., 2006). After the locking of the Apennines and southern Sicily (Gela nappe), shortening remained active offshore Calabria (Doglioni et al., 1999) and resumed along an active belt located in the southern Tyrrhenian region (Billi et al., 2007); as a consequence, a diffuse transform zone formed in NE Sicily and in the NW Ionian region to accommodate the remaining active portion of the slab beneath Calabria (D'Agostino and Selvaggi, 2004; Goes et al., 2004; Billi et al., 2006). The re-organization of the plate boundary is marked by two main processes: (1) 1-1.7 Ma, onset of uplift in Calabria; (2) $0.5 \mathrm{Ma}$, tholeitic magmas started to erupt, building up Mt. Etna, located on top of the western edge of the Calabria subduction zone.

The external part of the arc (Fig. 1) is represented by a subduction complex bordered by two major structural features: the Malta escarpment to the SW and the Apulia escarpment to the NE. The CA accretionary wedge developed due to the SE-NW African/Eurasian plate convergence, presently occurring at a very slow rate $\left(5 \mathrm{~mm} \mathrm{a}^{-1}\right.$ or less), according to recent Global Positioning System (GPS) studies (Calais et al., 2003; Reilinger et al., 2006; Serpelloni et al., 2007; D'Agostino et al., 2008; Devoti et al., 2008). Despite the very slow present-day plate convergence, subduction might be locally still active. GPS measurements of Calabrian site motion relative to Apulia show systematic residuals directed towards the Ionian Sea. This suggests active crustal compression and an outward motion of the CA as a result of active subduction and shortening taken up in the accretionary wedge, eventually accommodated by long-term slip on the subduction interface (Gutscher et al., 2006; D'Agostino et al., 2008). The submerged portion of the CA consists of a NW thickening wedge of deformed sediments (Finetti 1982; Cernobori et al., 1996; Minelli and Faccenna, 2010) overlying, in the most external portion, NW dipping sediments and the basement.

\subsection{The submarine subduction complex}

In this section we summarize the overall architecture and evolution of the CA subduction complex as derived from an integrated geophysical approach involving the analysis of seismic data at different scales (Polonia et al., 2011). Such architecture and evolution of the CA constitute the structural and geodynamic basis for the present study. 


\section{WESTERN LOBE}

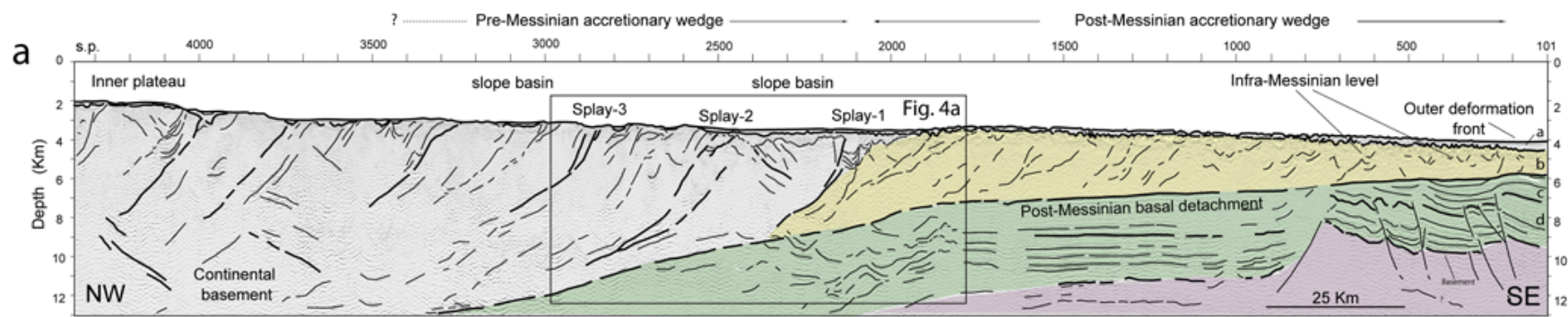

\section{EASTERN LOBE}

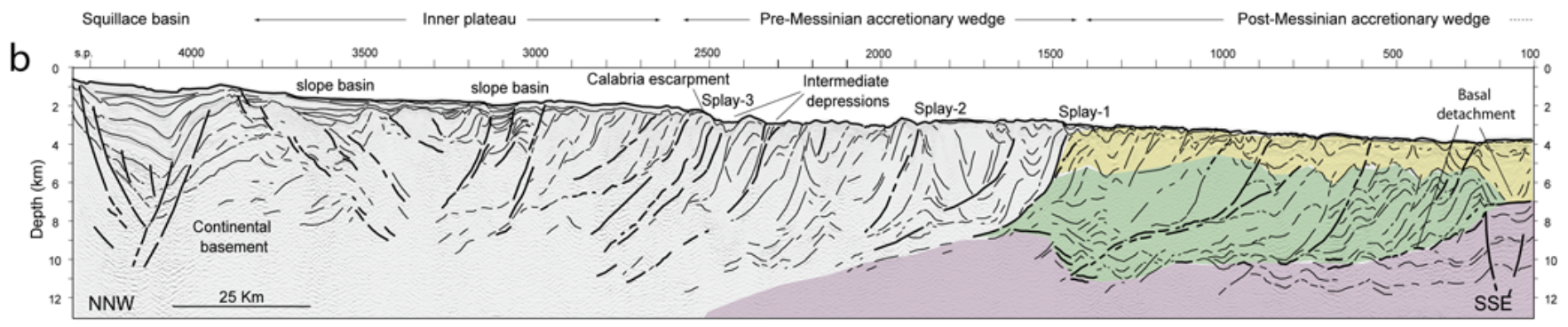

Fig. 2. (a) PSDM (Pre Stack Depth Migrated) MCS line CROP M-2B with superimposed line drawing. (b) PSDM 36 fold MCS line CROP M-4 and line drawing. Location of seismic profiles is shown in Fig. 1. These profiles have been collected in the western (offshore Sicily) and eastern (offshore Calabria) regions of the Calabrian Arc subduction complex, respectively. Yellow domain: Messinian and Plio-Quaternary sediments; green domain: Tertiary and Mesozoic sediments; light purple: African Plate basement.

Four main morpho-structural domains have been identified across-strike (Figs. 1 and 2). From SE to NW they are (1) the post-Messinian accretionary wedge; (2) a slope terrace; (3) the pre-Messinian accretionary wedge; and (4) the Inner Plateau. Variations of structural style and seafloor morphology in these domains are related to different tectonic processes, including frontal accretion, out-of-sequence thrusting, underplating and complex faulting.

The post-Messinian accretionary wedge (Figs. 1 and 2) is a salt-bearing accretionary complex, where frontal accretion of the Messinian and Plio-Quaternary units does actually occur along a basal detachment located at the base of the Messinian evaporites. The pre-Messinian accretionary wedge constitutes Tertiary and Mesozoic sediments, and the basal detachment is located either at the top of the Mesozoic carbonates or on the oceanic basement. Underplating processes and duplex formation are active in this region. The transition between post and pre- Messinian accretionary wedges is site of out-of-sequence thrusting that, as in the Nankai margin (Park et al., 2002; Tobin and Kinoshita, 2006; Kimura et al., 2007), has been called "splay faults". Complex faulting along the transition between the pre-Messinian wedge and the Inner Plateau causes fluid flow and mud diapirism (Panieri et al., 2012).

The CA subduction complex is segmented into two different lobes (Fig. 1) that show different basal detachment depths, structural styles and deformation rates (Fig. 2), interpreted as due to different rates of plate coupling on the subduction thrust. The western lobe (WL), offshore the Messina Straits region, has a very low tapered (taper about $1.5^{\circ}$ ), salt-bearing, outer accretionary wedge (Fig. 2a), bounded towards the continent by a slope terrace, which is the site of a Messinian thrust-top basin. The thrust-top basin develops in the region where the basal detachment cuts through deeper reflectors down to the basement. The eastern lobe (EL), in front of central Calabria, shows a completely different structure (Fig. 2b), with a more elevated accretionary wedge, 500-600 m shallower than in the western region, characterized by steeper topographic slopes and higher deformation rates.

The two lobes are delimited by a NW-SE deformation zone (Fig. 1) crossing the entire subduction complex from the abyssal plain to the Messina Straits. This newly proposed structure might represent the shallow expression of different stages of subduction and plate fragmentation in the Ionian Sea and reflects a recent phase of plate re-organization in the central Mediterranean. In particular, it bounds sectors of the WL where the slab is already detached and regions in the EL where local earthquake tomographic maps image a continuous slab penetrating into the mantle (Neri et al., 2009). Along this tectonic boundary, the WL is down-dropped relative to the EL.

Seismic data reveal that the subduction complex is segmented also to the $\mathrm{W}$, close to the Malta escarpment, where a 
Table 1. Major historical earthquakes in the working area (CPTI Working Group, 2004). The tsunamigenic events (Tinti et al., 2004) are marked with the TSUN label in the first column.

\begin{tabular}{llrrr}
\hline Date & Location & Lat N & Lon E & Maw \\
\hline 16 Jan 1975 & Messina Straits & 38.12 & 15.65 & 5.38 \\
28 Dec 1908 TSUN & Southern Calabria & 38.15 & 15.68 & 7.24 \\
23 Oct 1907 TSUN & Southern Calabria & 38.13 & 16.02 & 5.93 \\
20 Feb 1818 TSUN & Close to Catania & 37.6 & 15.13 & 6.00 \\
6 Feb 1783 TSUN & Southern Calabria & 38.22 & 15.63 & 5.94 \\
11 Jan 1693 TSUN & Eastern Sicily & 37.13 & 15.02 & 7.41 \\
10 Dec 1542 & Close to Syracuse & 37.22 & 14.95 & 6.62 \\
4 Feb 1169 TSUN & Eastern Sicily & 37.32 & 15.03 & 6.60 \\
7 Jun 1125 & Syracuse & 37.07 & 15.3 & 5.84 \\
31 Oct 853 & Messina & 38.1 & 15.65 & 6.30 \\
\hline
\end{tabular}

NNW-SSE trending transtensive fault is the shallow expression of slab tearing, whose existence was suggested also by previous authors (Rosenbaum et al., 2008).

\subsection{Historical earthquake record}

Despite the detailed earthquake catalogue (CPTI Working Group, 2004), knowledge of source parameters is relatively poor for most of the historical events. We analyse source area, intensity and areal effects of three major historical earthquakes $(1908,1693,1169)$ chosen among the list of known earthquakes (Table 1) on the basis of their magnitude and epicenter location, compatible with sources located offshore.

\subsubsection{The 28 December $1908 M_{\mathrm{w}}=7.24$ earthquake (Messina)}

On 28 December 1908, a strong earthquake of estimated $M_{\mathrm{W}}=7.2$ (CPTI Working Group, 2004) occurred in the Messina Straits. Within minutes after the earthquake, a tsunami with up to $11 \mathrm{~m}$ of runup height hit the coasts of Calabria and Sicily, as inferred from tsunami observations immediately after the disaster (Omori, 1909; Platania, 1909; Baratta, 1910) and from more recent estimates (Tinti and Giuliani, 1983; Tinti and Maramai, 1996; Tinti et al., 2004). These two events resulted in the destruction of the cities of Messina and Reggio Calabria and the loss of over 60000 lives.

Although it is generally agreed that the earthquake was the result of normal faulting in the Messina Straits, there are uncertainties over the specific location and throw of the causative fault. Several models of seismic source have been proposed (Schick, 1977; Valensise and Pantosti, 1982; Mulargia and Boschi, 1983; Bottari et al., 1986; Capuano et al., 1988; De Natale and Pingue, 1991; Amoruso et al., 2002), but to date, none of them has been able to fully explain the tsunami observations associated with the event (Pino et al., 2009).
Some uncertainties affect also the origin and reconstruction of the 1908 tsunami; its source area was reconstructed by Billi et al. (2008) using runup information and the delay between the earthquake and tsunami arrivals along the Calabrian and Sicilian coasts (Omori, 1909; Platania, 1909; Baratta, 1910). They concluded that the cause of the 1908 Messina tsunami was not only the displacement along a fault, but rather a submarine landslide in the Ionian Sea, although the responsible landslide has not been identified yet (Argnani et al., 2009a).

The contribution of the earthquake-related seafloor displacement to the generation of the tsunami is obvious from the geodetic data of Loperfido (1909), which imply a seafloor displacement on the order of $1 \mathrm{~m}$ (see also Valensise and Pantosti, 1992). It is also known that such a displacement can drive a runup of the same amplitude (Okal and Synolakis, 2004) or a bit more, if local amplifications exist. It follows that part of the 1908 tsunami runup must have been triggered by a landslide, in agreement with the observation of a slump and a turbidity current that produced two submarine cables breaks downslope along the margin (Ryan and Heezen, 1965) and models that include a composite source (e.g. earthquake and landslide) (Tinti et al., 2008; Tappin et al., 2008; Favalli et al., 2009).

\subsubsection{The 9 January $1693 M_{\mathrm{w}}=7.41$ earthquake (Sicily)}

A strong seismic sequence starting on 9 January 1693 hit eastern Sicily with the main magnitude $M_{\mathrm{w}}=7.41$ shock on 11 January (CPTI Working Group, 2004). The strong tsunami that followed caused 60000 casualties in eastern Sicily (Tonini et al., 2011). The identification of the fault planes responsible for the 1693 earthquakes is still an open issue. Among the offshore earthquake sources proposed in the literature (Bianca et al., 1999; Sirovich and Pettenati, 1999; Monaco and Tortorici, 2000; Gutscher et al., 2006), the most likely rupture area appears to be located close to the Malta escarpment, since it provides the best fit with tsunami observations (first wave polarity and wave amplitude). On the other hand, the tsunami scenario proposed by Tonini et al. (2011), taking into account the hypothesis of an earthquake-triggered tsunami (set of normal faults at the toe of the Malta escarpment as proposed by Argnani and Bonazzi, 2005), does not fit the observations and underestimates the tsunami effects. As in the case of the 1908 earthquake, the possibility that the 1693 tsunami was induced by a submarine landslide cannot be ruled out, as proposed by Billi et al. (2010) through the analysis of the runup field.

\subsubsection{The 4 February $1169 M_{\mathrm{w}}=6.6$ earthquake (eastern Sicily)}

Very little information exists on this earthquake, mainly because very few historical documents are available. The earthquake destroyed Catania, while Lentini was seriously 
damaged, even if it is not possible to reconstruct in detail the damage that affected eastern Sicily (Boschi et al., 1997).

\section{Methods}

In this study we used a multi-disciplinary and multi-scale geophysical approach to resolve the shallow geometry and kinematics of three fault systems in the Ionian Sea. Acquisition and processing parameters of the geophysical data are summarised in Table 2.

Deep penetration seismic profiles (CNR_ENI Deep Crust Seismic Profiles - CROP, Figs. 1 and 2) were used to reconstruct the overall geometry of the subduction complex, i.e. depth of the basal detachment, geometry and structural style of different tectonic domains, and location and geometry of major faults. High-resolution multi-channel seismic (MCS) profiles (CALAMARE dataset), Sparker data acquired by IGM (now ISMAR-Bo) in the Ionian Sea during the 1970s (Rossi and Sartori, 1981), sub-bottom CHIRP profiles recently acquired in key areas of the CA (Fig. 3) and multibeam data integrate deep seismic data and constrain the fine structure of the accretionary wedge as well as the activity of individual fault strands.

\section{Active faults in the subduction complex}

The integrated analysis of the multi-scale geophysical dataset revealed both compressive and transtensive deformation in the inner portions of the subduction complex. Three major tectonic structures were analysed on the basis of their seismogenic potential.

\subsection{Splay fault system}

A series of out-of-sequence thrust faults (splay faults) develops at the transition between the outermost salt-bearing accretionary wedge and the pre-Messinian accretionary complex (Fig. 2). These faults accommodate the structural contrast between a shallow, rather flat and very weak décollement in the frontal wedge (base of the evaporites) and a deeper, stronger and steeper basal detachment within the pre-Messinian sediments.

The splay faults region hosts sedimentary slope basins in the WL (Fig. 2a, S. P. 1900-2500) and a series of topographic lows in the EL, known as "intermediate depressions" (Fig. 2b, S. P. 2300-2500) after Rossi and Sartori (1981). These features are the seafloor expression of three major deeply rooted thrust faults well imaged on deep penetration seismic profiles as continuous, high amplitude and landward dipping seismic reflectors. Their morphological expression at the seafloor (Fig. 1), as well as their dip, strike and continuity vary in the two lobes (Fig. 2).

In the WL, offshore Sicily and the Messina Straits, the average dip of the structures, as deduced from the PSDM

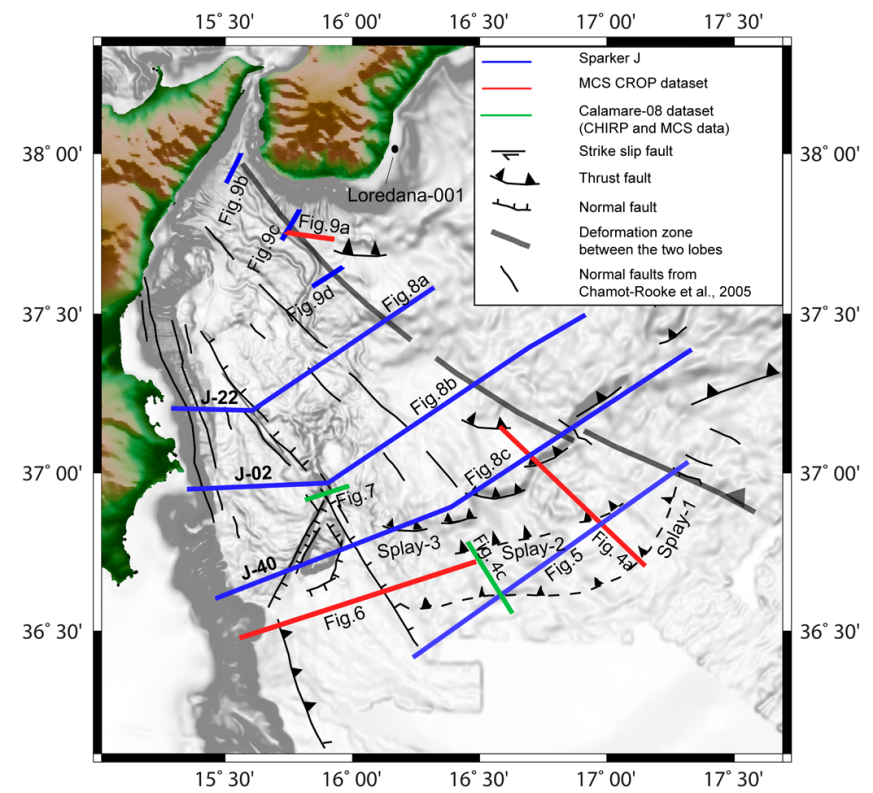

Fig. 3. Shaded relief morpho-bathymetric map compiled using data collected during different cruises by the CIESM/IFREMER Medimap group (Loubrieu et al., 2008). Major faults derived from the tectonic model of Polonia et al. (2011) are indicated and labelled STEP, Splay-1, -2, -3, while the thick, discontinuous, NW-SE trending orange lines offshore the Messina Straits represent the boundary between the two lobes, which is marked by a diffuse area of deformation related to scarps, ridges and troughs. Seismic data from the different datasets used in this work are represented by red, blue and green lines. These lines represent the segments of the profiles shown in this manuscript. Location of Loredana-001 well is indicated.

seismic profiles (Figs. 2a and 4a), is about $20^{\circ}$ in the upper section, while it decreases to $12-13^{\circ}$ downwards. Fault strike and continuity have been reconstructed through the integrated analysis of multibeam data and seismic profiles (Figs. 1, 2 and 3). On the morpho-bathymetric map, the proposed active splay faults are represented by WNW/ESE striking en-echelon left stepping ridges, about $10-20 \mathrm{~km}$ long. Their regional trend follows the overall curvature of the WL of the CA.

Splay-3 is the most prominent of the proposed out-ofsequence thrust faults, as it corresponds to the discontinuous topographic scarp present at about $3000 \mathrm{~m}$ water depth, with a series of 4-5 major overstepping ridges (Figs. 2 and 3). This thrust fault is in agreement with the directions of maximum and minimum horizontal contractional strain rates reported by Jenny et al. (2006).

Multibeam data suggest that splay faults are associated with active deformation at the seafloor, as imaged also in the seismic reflection profile CROP M-2B (Fig. 4a and b) and in the sub-bottom CHIRP profile across Splay-1 (Fig. 4c), showing that this tectonic structure is associated with kmscale, $200 \mathrm{~m}$ high seafloor swells. In our interpretation, these wide seafloor swells across the rather flat slope terrace (thrust 
Table 2. Acquisition parameters, processing sequence and resolution of geophysical data used in this study.

\begin{tabular}{|c|c|c|c|c|}
\hline $\begin{array}{l}\text { GEOPHYSICAL } \\
\text { MULTI-SCALE } \\
\text { DATASET }\end{array}$ & Acquisition parameters & $\begin{array}{l}\text { Main processing } \\
\text { sequence }\end{array}$ & $\begin{array}{l}\text { Resolution } \\
\text { in space }\end{array}$ & $\begin{array}{l}\text { Resolution } \\
\text { in time }\end{array}$ \\
\hline $\begin{array}{l}\text { Deep penetration } \mathrm{MCS} \\
\text { (CROP dataset) }\end{array}$ & $\begin{array}{l}\text { Source: } 4906 \mathrm{cu} \text { inch air guns } \\
\text { Streamer: } 4500 \mathrm{~m} \\
\text { Group interval: } 25 \mathrm{~m} \\
\text { Shot interval: } 62.5 \mathrm{~m} \\
\text { Coverage: } 3600 \% \\
\text { Sample interval:: } 4 \mathrm{~ms}\end{array}$ & $\begin{array}{l}\text { Full pre-stack depth-migration } \\
(\text { PSDM), with SIRIUS/GXT, Migpack } \\
\text { software package. }\end{array}$ & km-scale & $n \times \mathrm{Ma}$ \\
\hline $\begin{array}{l}\text { High-resolution MCS } \\
\text { seismic (CALAMARE) }\end{array}$ & $\begin{array}{l}\text { Source: } 2 \text { Sodera G.I. guns, } \\
\text { Streamer: } 600 \mathrm{~m} \\
\text { Group interval: } 12.5 \mathrm{~m} \\
\text { Shot interval: } 50 \mathrm{~m} \\
\text { Coverage: } 600 \% \\
\text { Sample interval.: } 1 \mathrm{~ms}\end{array}$ & $\begin{array}{l}\text { Velocity analysis, stack, DMO, velocity } \\
\text { analysis, stack }\end{array}$ & $\begin{array}{l}\mathrm{hm} \text { to } \mathrm{km} \\
\text { scale }\end{array}$ & $\mathrm{Ma}$ \\
\hline Sparker seismic data & $\begin{array}{l}\text { Source: } 30 \mathrm{~kJ} \text { Teledyne system. } \\
\text { Streamer: active section } 50 \mathrm{~m} \text {, } \\
\text { single channel } \\
\text { Shot interval: } 4-8 \mathrm{~s}(12-24 \mathrm{~m})\end{array}$ & $\begin{array}{l}\text { Data, available only in hard copies. } \\
\text { Data have been digitized, processed } \\
\text { and geo-referenced using the open- } \\
\text { source software Seisprho (Gasperini } \\
\text { and Stanghellini, 2009). }\end{array}$ & $n \times 100 \mathrm{~m}$ & $n \times \mathrm{ka}^{-1}$ \\
\hline $\begin{array}{l}\text { Sub-bottom } \\
\text { Seismic data }\end{array}$ & $\begin{array}{l}17 \text { hull mounted } 17 \text { transducers } \\
\text { CHIRP- Benthos sonar system } \\
\text { (3-7 KHz sweep frequency) }\end{array}$ & $\begin{array}{l}\text { Data represented through variable den- } \\
\text { sity section with instantaneous ampli- } \\
\text { tude }\end{array}$ & $\begin{array}{l}\text { Metric/ } \\
\text { decimetric } \\
\text { scale }\end{array}$ & $\begin{array}{l}\text { Thousand/ } \\
\text { hundred } \\
\text { years }\end{array}$ \\
\hline $\begin{array}{l}\text { Multebeam data } \\
\text { (IFREMER, } \\
\text { MEDIMAP group, } \\
\text { Lebeuyer, Mascle et al., } \\
2008 \text { ) }\end{array}$ & Simrad EM-300 & $\begin{array}{l}500 \mathrm{~m} \text { grid provided by the MEDIMAP } \\
\text { group }\end{array}$ & $500 \mathrm{~m}$ grid & Present \\
\hline
\end{tabular}

top basin) represent the shallow expression of compressional features related to the activity of the deeply rooted Splay-1 fault system.

The Splay-1 fault system is represented in Sparker profile J-04 (Fig. 5) by wide topographic highs between sedimentary basin depocenters. In this region the out-of-sequence thrust fault system is very close both to the Malta STEP fault system to the west (ping 143) and to the deformation zone between the two lobes of the subduction complex to the east (ping 100). In this narrow region, the three fault systems interfere with each other, producing a complex structural setting, where double verging thrust faults are present, and the wedged-shaped sedimentary basin of the Malta STEP fault system (Fig. 5b) is located very close to the folds related to the Splay-1 thrust system (Fig. 5c).

In the EL offshore Calabria, the out-of-sequence trust faults are associated with a more complex structural setting (Fig. 2b), and a generally rougher seafloor (Figs. 1 and 2b). The average dip of the Splay-1, -2 and -3 is about $26-30^{\circ}$ and thus steeper than those in the WL. Splay-3, in particular, is a major regional tectonic feature, the Calabrian escarpment (Fig. 1), segmenting across-strike the EL (Polonia et al., 2011). The NE-SW trending Calabria escarpment is the shallow expression of Splay-3, represented at the seafloor by a topographic scarp, where the seafloor deepens to more than $700 \mathrm{~m}$ from the rather flat Inner Plateau (average water depth $2000 \mathrm{~m}$ ) to the intermediate depressions $(2800-3000 \mathrm{~m}$ water depth). Splay-3 is the northernmost compressional feature imaged on the seismic profiles (Fig. 2b); landwards of this thrust fault, extensional structures mark the development of sedimentary basins in the Inner Plateau, such as the Squillace basin (Fig. 2b).

\subsection{Malta STEP (Slab Transfer Edge Propagator) fault system}

The western lateral boundary of the CA is represented by the Malta escarpment, a major regional NNW-SSE trending morphological feature that has been described as a right lateral transtensional system (Doglioni et al., 2001). Reprocessing and re-interpretation of CROP M-3 seismic profile (Fig. 6) clarified the relationships between the Malta escarpment and the subduction complex. The lower continental slope is disrupted at the toe of the Malta escarpment along two east-dipping normal faults, which produce two steep scarps of about 700 and $1000 \mathrm{~m}$. At the base of the slope, the 
a PSDM SEISMIC LINE CROP M-2B

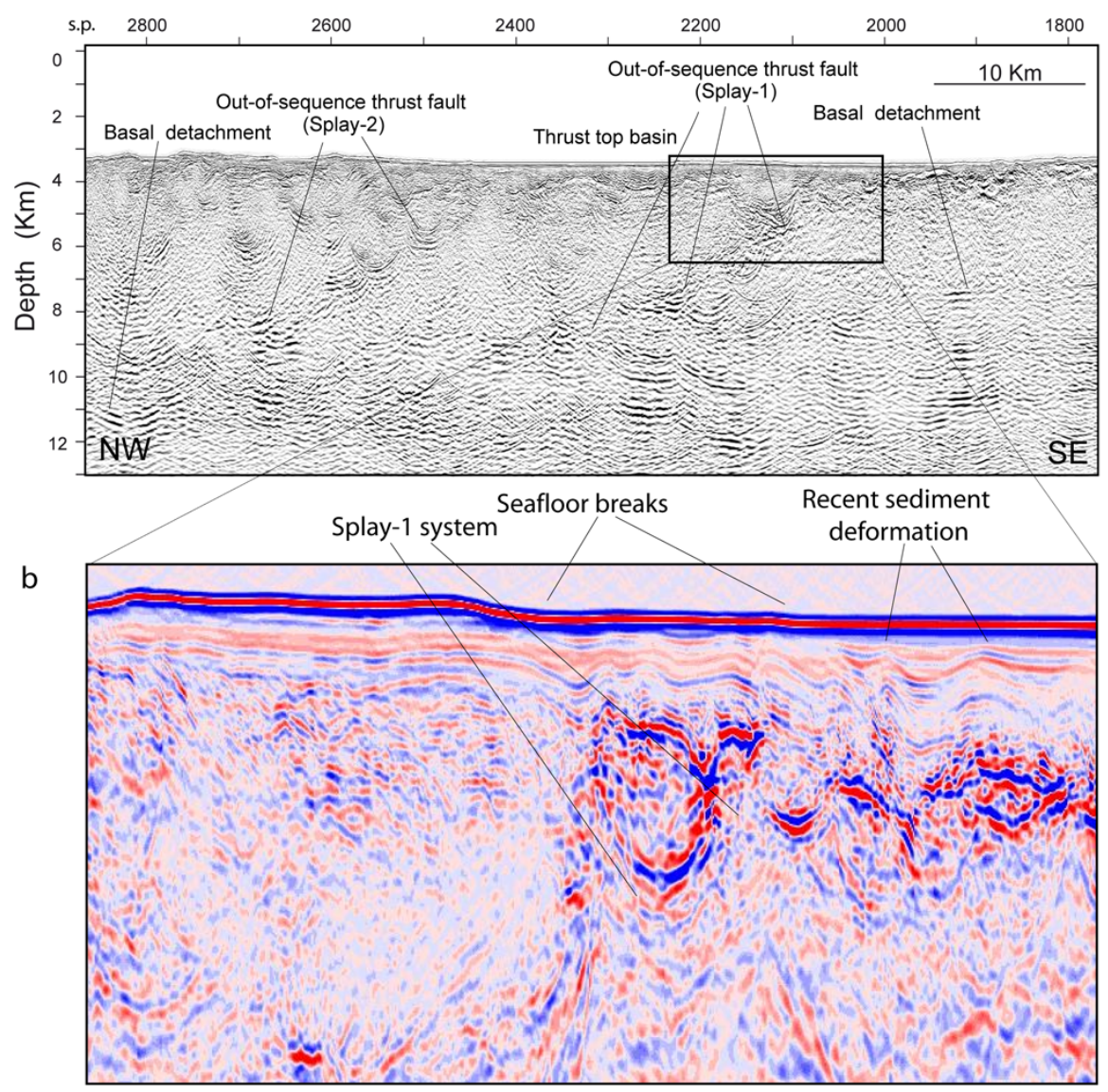

C SUB-BOTTOM CHIRP PROFILE ACROSS THE SPLAY-1 SYSTEM

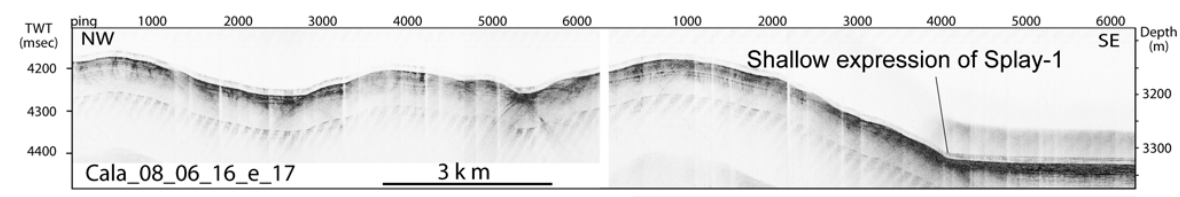

Fig. 4. (a) Close-up view of MCS line CROP M-2B across the slope terrace at the transition between the post-Messinian salt-bearing complex and pre-Messinian wedge (see Figs. 2 and 3 and 3 for location). (b) Sub-bottom CHIRP profile collected in the same area shows how splay fault is associated with large wavelength folding of the seafloor, suggesting active or at least recent deformation.

flat Plio-Quaternary sediments onlapping the lower continental slope suggest that faulting is no longer active on the escarpment, although higher resolution data is needed to better constrain relationships between tectonics and sedimentation. The post-Messinian accretionary wedge (Fig. 6) is sealed by recent sedimentation and by a 700-m-thick, wedge-shaped, chaotic body, thinning out towards NE. This suggests that frontal accretion stopped in this part of the continental margin during Pliocene times.

About $70 \mathrm{~km}$ east of the toe of the Malta escarpment, a sub-vertical crustal fault system and an upper listric fault outcropping at the seafloor displace the accretionary wedge, as well as deeper reflectors, and control the formation of a fan-shaped basin, whose geometry suggests syn-tectonic sedimentation above an east-dipping transtensive fault (Fig. 6). The geometry of the sedimentary basin and the displacement of the seafloor (Fig. 6) suggest that this fault is presently active, as confirmed by the presence of submarine canyons and topographic scarps aligned along the fault strands (Figs. 1 and 7).

The average dip of the shallow fault system is about 25$30^{\circ}$, while downwards it flattens out. The deeply rooted part of the fault system below the accretionary wedge is represented by the high angle fault dipping towards E that may represent a major deeply rooted Mesozoic normal fault. The Malta STEP fault system is rather continuous from the lower 


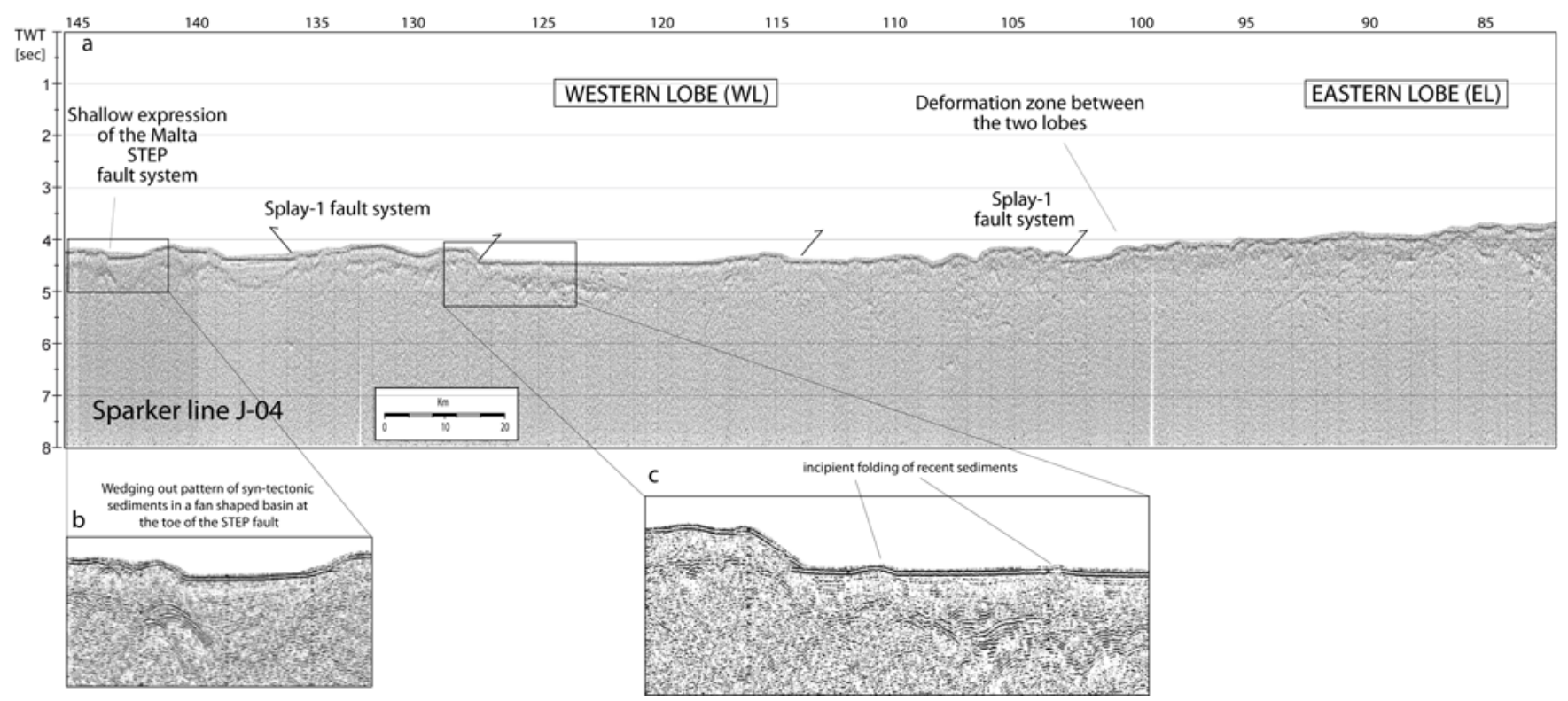

Fig. 5. Sparker seismic profile J-04 across the mid-slope terrace east of Sicily (see Fig. 3 for location) and the Splay-1 fault system, represented in this profile by wide swells between sedimentary basin depocenters. Splay-1 system is crossed twice by the SW-NE trending Sparker profile.

continental slope, close to the Etna volcano, down to the midslope terrace (Fig. 1), along a N $30^{\circ} \mathrm{W}$ direction for a length of about $120-150 \mathrm{~km}$. It can be followed along the continental margin from available geophysical data, as shown in Fig. 7, where high-resolution MCS (time-migrated seismic profile CALA-02) and CHIRP sub-bottom seismic data show that the Malta STEP fault is associated with basin formation, sediment disruption and vertical throw of seismic reflectors.

This fault system is a major tectonic structure that segments the subduction complex close to a continental corner and for this reason may be considered as the shallow expression of a STEP fault (Govers and Wortel, 2005) accommodating tear at the slab edge. It results in a complex deformation pattern, topography and sedimentary basin formation at the transition between the salt-bearing post-Messinian complex and the pre-Messinian clastic wedge, in a region where the basal detachment cuts to deeper levels (Fig. 6). For this reason, we propose that the Malta STEP fault system represents a re-activation of the Splay-1 as a transtensive fault during recent times. Sediment thickness in the basin depocenter is about $700 \mathrm{~m}$, and this observation can be used to reconstruct fault inception. The average Holocene sedimentation rate in the working area is about $0.1-0.2 \mathrm{~m} \mathrm{ka}^{-1}$, as deduced from the analysis of sediment cores collected during the CALAMARE cruise (Polonia et al., 2012). The peculiar location of the sedimentary basin imaged in CROP line M-3 (Fig. 6), close to the canyon systems from the Messina Straits, suggests sedimentation rates higher than average sedimentation in the area. With these assumptions, we estimate that the sedimentary basin in CROP profile M-3 is younger than midPliocene.

All the structures described in this work are visible and can be followed laterally in three WSW-ENE trending sparker profiles (J-22, J-02, J-40) crossing the continental margin offshore the Messina Straits from north to south (Fig. 8). The STEP fault system is represented by the depressions and sedimentary basins visible east of the Alfeo seamount (Fig. 8b and $8 \mathrm{c}$ ), while to the north, it corresponds to the transition between the sedimentary basin and the chaotic rock assemblage of the western lobe (Fig. 8a). In the Sparker profiles of Fig. 8, only the northernmost Splay-3 fault system is visible. The deformation zone between the two lobes of the subduction complex is imaged in all of the profiles and is represented by a wide area of deformation bounding the more elevated and more chaotic EL and the more depressed and less corrugated WL.

\subsection{The deformation zone between the two lobes in the Messina Straits region}

The two lobes of the CA are bounded by a diffuse area of deformation, whose character changes along fault strike. In the outermost salt-bearing accretionary wedge, the two lobes are separated by low angle NE dipping reverse faults, along which the EL is overriding the WL (Polonia et al., 2011, their Fig. 14). Along this structural boundary, km-scale confined sedimentary basins and depressions align as a result of the interplay between tectonics, fluid flow and salt dissolution (Fig. 1). In the inner portions of the accretionary wedge, the boundary between the two lobes is related to topographic 

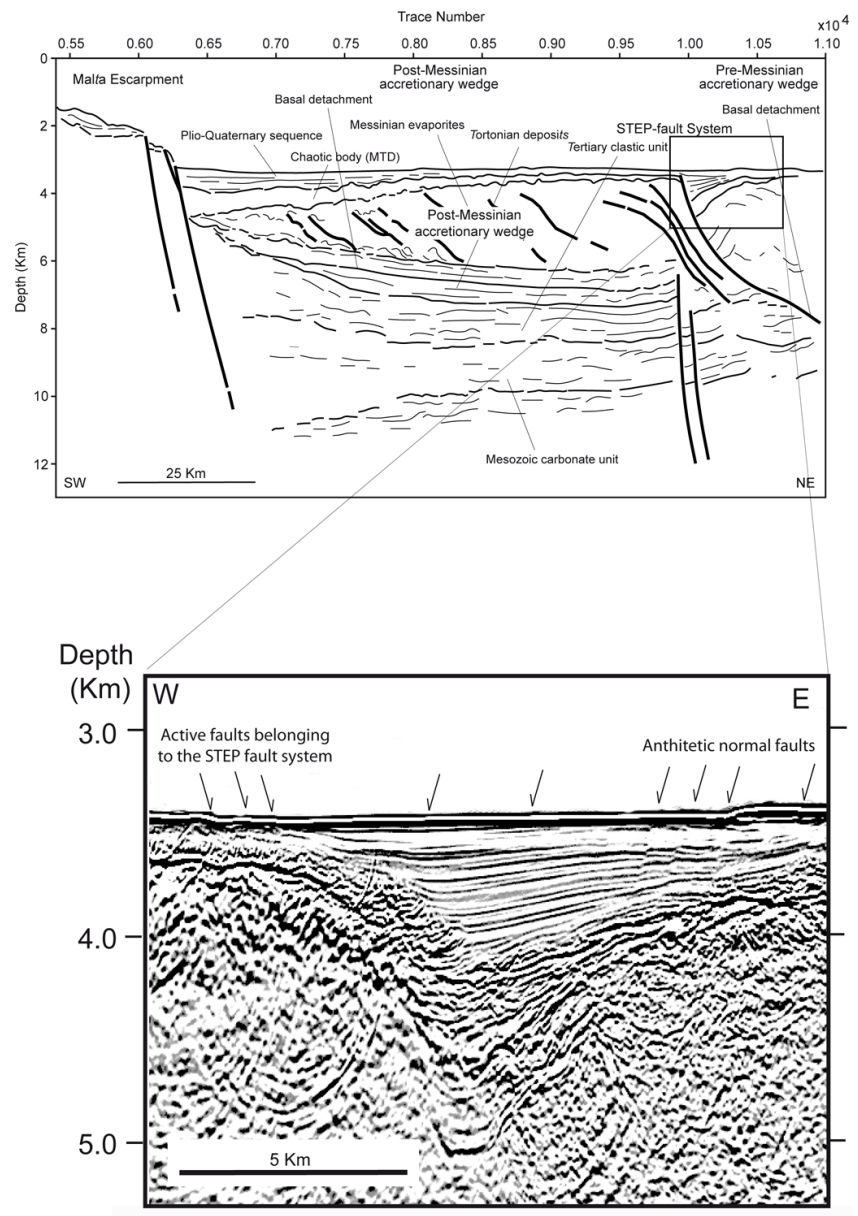

Fig. 6. Above: line drawing of pre-stack depth migrated 36 fold MCS line CROP M-3 across the transition between the Malta escarpment and CA accretionary wedge (see Fig. 3 for location). At the toe of the Malta escarpment, the post-Messinian salt-bearing complex lies on the basal detachment and is covered by a $800-\mathrm{m}-$ thick chaotic body (MTD). At trace number 1, a crustal-scale fault system is imaged; this is the shallow expression of a "STEP" fault (Govers and Wortel, 2005). Below: zoom of the sedimentary basin showing active deformation reaching the seafloor.

scarps and rectilinear features, suggesting it may be better described as a transtensive and/or transpressive tectonic structure.

To study this major structural boundary segmenting across-strike the subduction complex in the region close to the Messina Straits, we have re-processed (Pre Stack Depth Migration) and re-interpreted the WNW-ESE trending MCS line CROP C92-31 (Figs. 3 and 9a), which crosses the offshore region of the Messina Straits. This region is challenging for studying active tectonics, because strong bottom currents and complex sediment dynamics in the shallow seafloor $(<500 \mathrm{~m})$ overprint morphostructural features along active faults. In deeper waters, the potential of preservation of any tectonically-related topographic feature at the seafloor should increase.

Deep penetration CROP seismic profile C92-31 (Fig. 9a) clearly shows that a major sub-vertical fault displacing the seafloor is imaged down to a depth of about 6-7 km. The subvertical fault bounds two distinct structural domains: a welllayered unit to the west and a chaotic rock assemblage to the east. This sharp transition is marked by opposite dipping reflectors in the two blocks (westward dipping to the west and eastward dipping to the east).

West of the fault, we observe a $3.5-\mathrm{km}$-thick, very wellstratified and relatively undeformed sedimentary section slightly dipping towards the WNW. Correlation with seismic profiles collected in better known regions to the north, where direct correlation with log data from Loredana-001 well (Fig. 3) and field stratigraphy is possible, defines the stratigraphic framework of these units. Below the seafloor, $550 \mathrm{~m}$ of mid-Pliocene and Quaternary well-layered sediments overlie an angular unconformity, possibly related to the regional middle-late Pliocene tectonic event described in the surrounding areas (Praeg et al., 2009). Below this unconformity, 300-600 $\mathrm{m}$ of Pliocene sediments rest on the Messinian evaporites and Tertiary (Late Miocene-Late Oligocene) sediments imaged on the Aspromonte units. The basement is located at about $5000 \mathrm{~m}$. To the east of the proposed sub-vertical Messina Straits fault, the rock assemblage is very different: stratigraphic correlations are hampered by poor reflectivity due to sediment deformation, and only few seismic reflectors are visible.

We propose that the sub-vertical structure bounding the two completely different domains is a major fault belonging to the deformation zone between the eastern and the western lobes of the accretionary wedge. This structure accommodates differential movements of the Calabrian and the Peloritan portions of the CA and might account for the NW-SE extension observed in the Messina Straits, as well as the relative motion between Calabria and NE Sicily. The MCS profile CROP c92-31 (Fig. 9a) suggests that this fault system corresponds to a pre-existing reverse fault that has been recently re-activated as a transtensional structure similarly to the STEP fault system to the SW. Normal faulting is present in the very shallow sediments: the seafloor shows topographic breaks and scarps, while seismic reflectors show extensional deformation down to $3 \mathrm{~km}$ b.s.f. This is in agreement with the directions of maximum and minimum horizontal contractional strain rates reported by Jenny et al. (2006) and shown in Fig. 10.

The activity of this fault was investigated through the analysis of high- resolution seismic data (Fig. 9b, c and d) showing a series of topographic scarps and submarine canyons associated with displacement of sedimentary units and vertical throws of seismic reflectors along the fault.

On the basis of our reconstruction, the Messina Straits fault system may be described as a right lateral transfer system that, together with the STEP fault system, connects the 


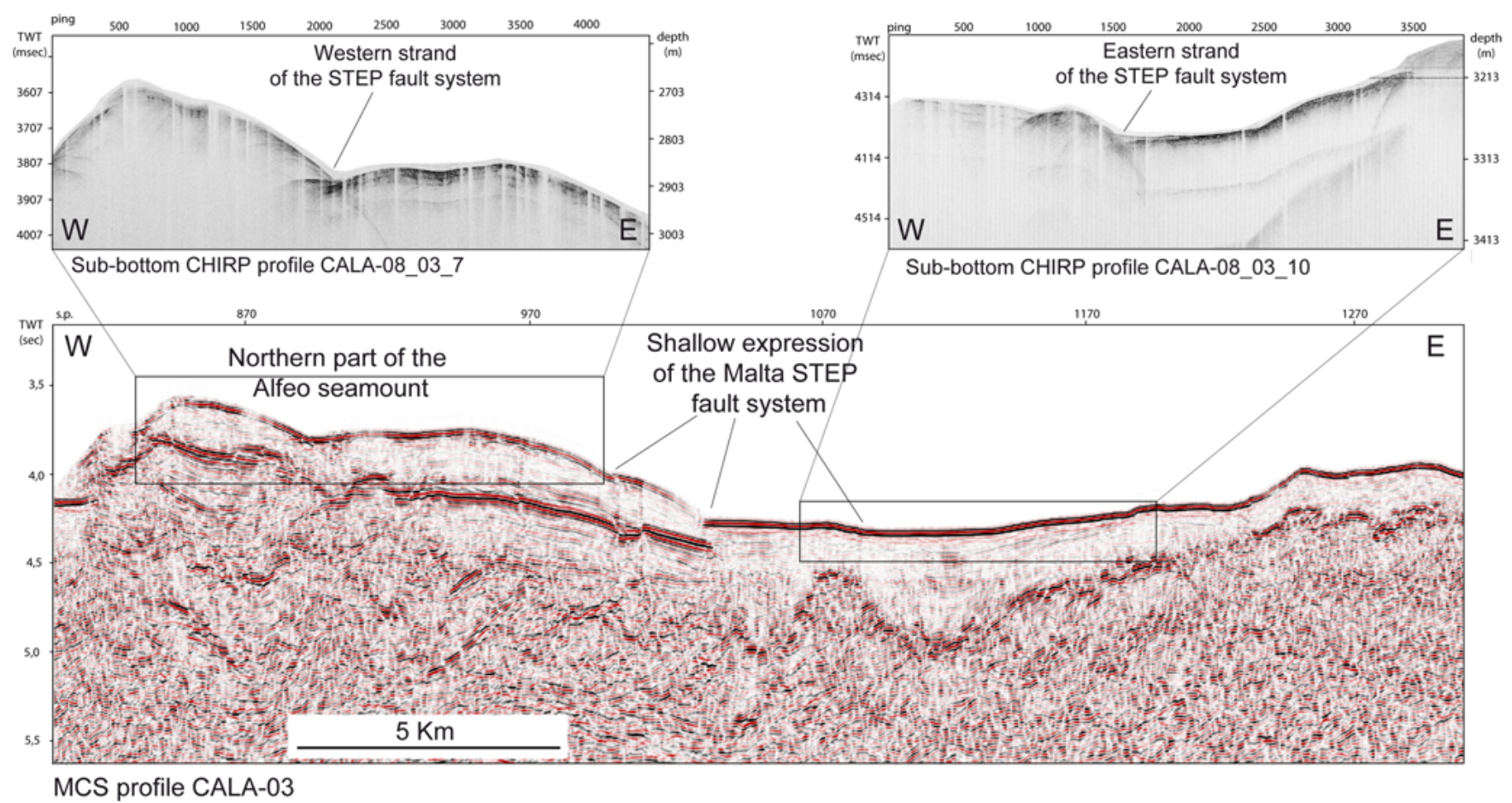

Fig. 7. High-resolution multichannel time-migrated seismic profile CROP M-3, CALA-02 and CHIRP sub-bottom seismic data across the Malta STEP fault system. Active faulting is associated with basin formation, sediment disruption and vertical throw of seismic reflectors.

plate boundary in northern Sicily to the outer deformation front in the Ionian Sea. We observe that, similarly to other continental transforms, it could be characterized by a wide deformation zone made of releasing and restraining bends. In this setting, subsidence within the Messina Straits could be explained by a set of NW-SE right stepping fault segments.

\section{Discussion}

\subsection{Submarine seismogenic faults and their geodynamic significance}

The described active faults in the submerged portion of the CA (Fig. 10) are first order, deeply rooted, and relatively long tectonic boundaries, delimiting sectors of the margin with different deformation rates. Moreover, they are associated with secondary structures towards the surface, whose signature is more diffused and marked by a complex topography and sedimentary basin formation. The multi-scale geophysical analysis we carried out produced a hierarchy of the tectonic structures, where each single fault strand was described within the geodynamic framework of the central Mediterranean region and the overall African/Eurasian plate convergence.

The Malta STEP fault system connects the Tindari fault and the African Plate compressive margin along the northern coasts of Sicily (Billi et al., 2007) to the outer deformation front of the subduction system in the Ionian Sea. The saltbearing complex close to the Alfeo seamount is sealed by recent sedimentation, suggesting that frontal accretion is presently inactive in this region and the plate boundary is more diffused. MCS data do not allow to reconstruct in detail whether this fault produces deformation in deep crustal levels. However, the top of the basement appears to be displaced along the fault plane.

High-resolution local earthquake tomography defines the geometry of the subduction zone, which appears as an extremely narrow slab enlarging at depth (Neri et al., 2009). The portion of the slab beneath the EL (Fig. 1) is continuous, while below NE Sicily low-velocity anomalies suggest that slab detachment has already occurred. Regional tomographic and seismic reflection data confirm that the proposed Malta STEP fault system may represent the shallow expression of a new plate boundary resulting from slab tearing and can be seen as a transfer fault system accommodating different deformation rates in Sicily and Calabria. Relative motion along the transform segments of the plate boundaries is often nonuniform, and the STEP is not a classical strike slip feature, because it propagates within deformed domains causing substantial deformation, rotation, topography and sedimentary basins with a very specific time-space evolution. The scarcity of strike slip earthquakes in some of the known STEP regions (Bilich et al., 2001) has been ascribed to alternating periods of STEP propagation and loading (Govers and Wortel, 2005). The observed seismicity (CPTI Working Group, 

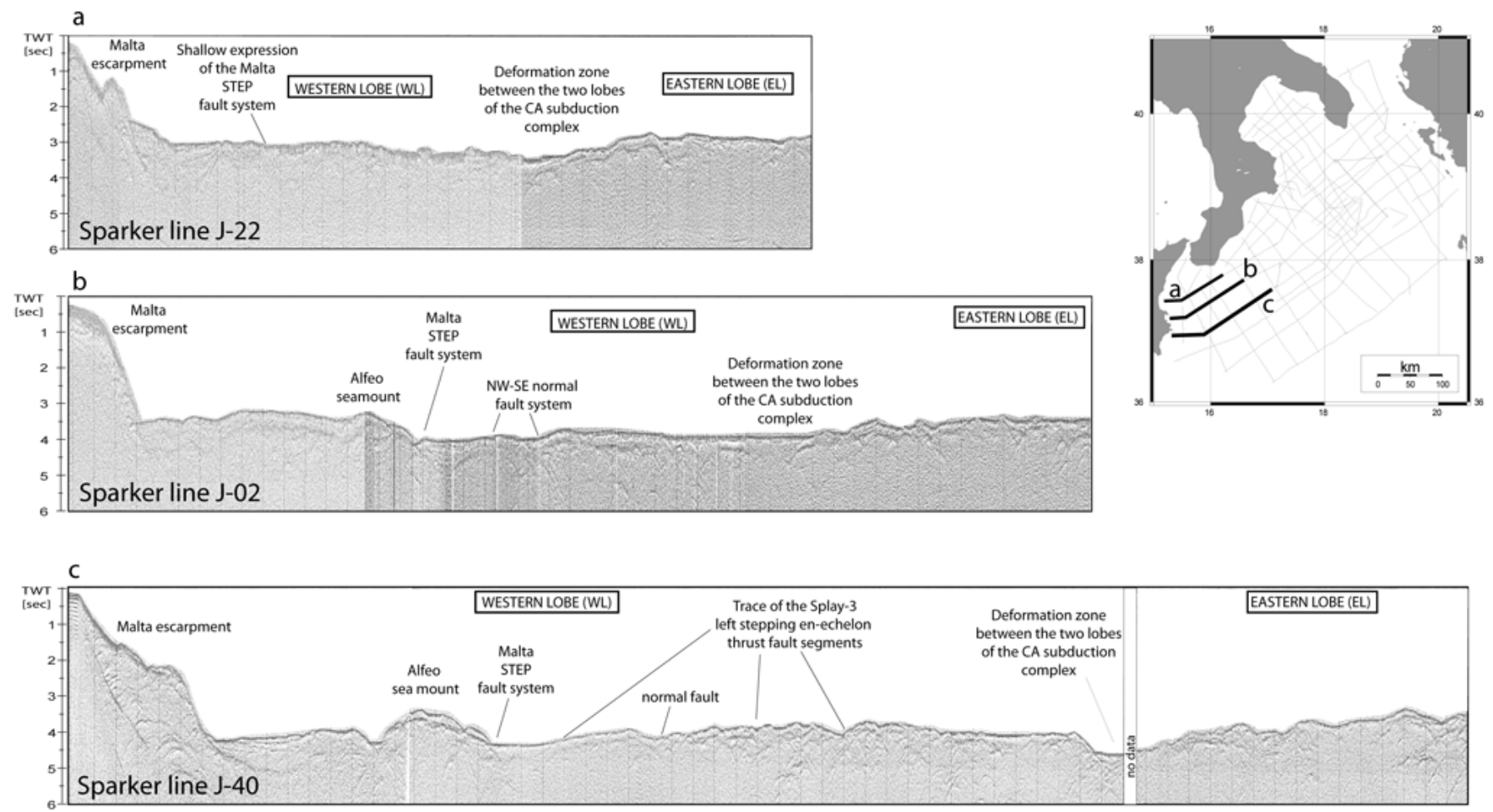

Fig. 8. WSW-ENE trending sparker seismic profiles J-022, J-02, J-40 across the western continental margin offshore the Messina Straits region (see Fig. 3 for its location). All the structures described in this work are visible and can be followed laterally. The STEP fault system is represented by the depressions and sedimentary basins visible east of the Alfeo seamount (b and $\mathbf{c}$ ), while Splay-3 fault system is crossed by the seismic profile at least twice (see Fig. 3 for location). The deformation zone between the two lobes of the subduction complex is imaged in all of the profiles and is represented by a wide area of deformation, bounding the more elevated and more chaotic eastern lobe offshore Calabria and the more depressed and less corrugated western lobe.

2004) along the NW part of the proposed Malta STEP fault system (Fig. 10) suggests that in this region, the STEP fault is under propagation and may generate large earthquakes in the near future.

The splay faults described in this work are long thrust faults that rise from the subduction plate boundary megathrust and intersect the seafloor at the landward edge of the post-Messinian accretionary wedge. Splay-1, in particular, represents the boundary between the wedge emplaced before and after the Messinian salinity crisis. This paleoceanographic event caused the beginning of a new subduction cycle in the Mediterranean Sea (DeCelles and Cavazza, 1995) that changed the geometry of the evolving submarine subduction complex. Splay faults may have activated during and after the Messinian crises to re-establish wedge equilibrium, when part of the outer accretionary complex had already formed. This is in agreement with reconstructions of major tectonic phases in the CA (Steckler et al., 2010), which describe a mid-late Pliocene strong shortening tectonic phase.

The splay faults are regional features present in both lobes of the CA (Fig. 2a and b), and they formed before margin segmentation. If subduction processes are still active, splay fault branches may be also active and deform co-seismically.
If subduction has already ceased in the CA and the African Plate is not underthrusting below the Eurasian Plate, splay faults could represent features that accommodate the still ongoing plate convergence.

Out-of-sequence thrust faults in the inner part of subduction complexes are seismogenic features capable of producing large earthquakes, because they may accommodate variation in slip rate on the deep part of the subduction interface (Shaw et al., 2008). This kind of faulting is common in subduction zone settings: out-of-sequence thrust faults have been imaged at the landward edge of the Nankai accretionary prism off Japan, (Park et al., 2002; Moore et al., 2007) and off Sumatra (Gulick et al., 2011). Splay faults along the Nankai margin have received great attention, because they may transfer efficiently displacement to the sea surface, inducing the formation of tsunami (Moore et al., 2007). A recent IODP (Integrated Ocean drilling Program) drilling across splay faults shows that splay branches may be also active and deform co-seismically (Kimura et al., 2011). A major out-of-sequence reverse fault, dipping beneath Crete and cropping out near the Hellenic Trench, has been described as the source of the $M=8.3-8.5365$ AD Cretan earthquake that destroyed cities and drowned thousands of 

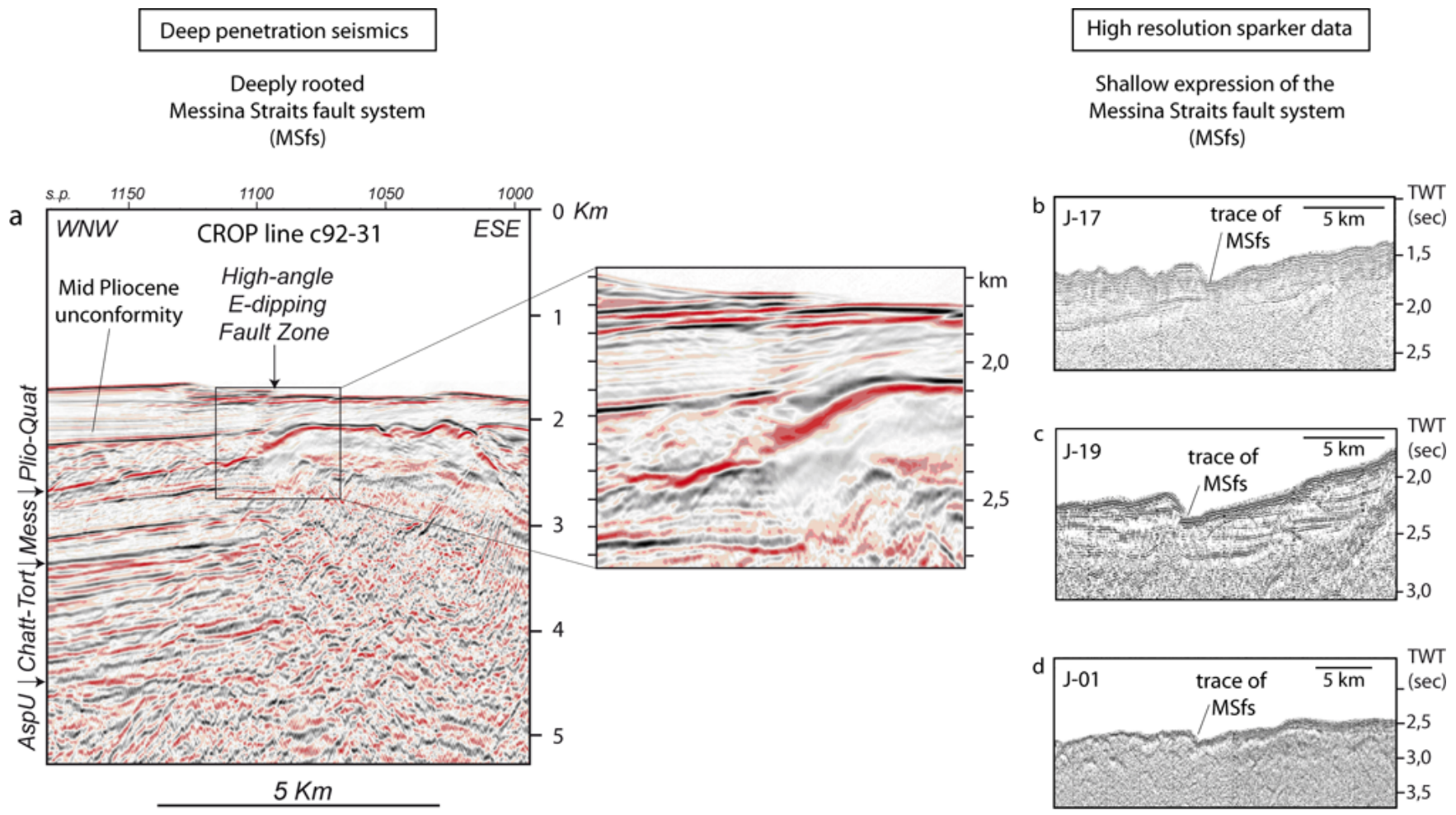

Fig. 9. (a) PSDM MCS line CROP C92-31 across one of the tectonic features belonging to the deformation zone between the two lobes. A major sub-vertical fault displacing the seafloor is imaged down to about $6-7 \mathrm{~km}$ of depth. The sub-vertical fault bounds two completely different structural domains, and fault planes correspond to the sharp transition from well-layered units to the west and a chaotic rock assemblage to the east. (b) NNE-SSW trending sparker seismic profiles J-17, J-19, J-01 across the western continental margin offshore the Messina Straits region (see Fig. 3 for its location). Topographic scarps and sedimentary features are present along the fault trace. AspU: Aspromonte Unit; Chatt-Tort: Chattian-Tortonian units; Mess: Messinian units; Plio-Quat: Plio-Quaternary units.

people in coastal areas from Africa, Greece, Sicily and the Adriatic (Shaw et al., 2008). Slip on a similar fault is thought to have caused the $10 \mathrm{~m}$ uplift of Monteague Island during the 1964 Alaska earthquake (Ichinose et al., 2007). Splay fault geometry makes these active continental margins particularly prone to tsunami genesis.

The newly proposed Messina Straits fault system is the NW segment of the deformation zone between the two lobes of the accretionary complex. In the outer accretionary wedge, the deformation zone is related to low angle, eastward dipping reverse faults, while close to the Messina Straits and southern Calabria, it is represented by topographic scarps, tectonic lineaments and sub-vertical, or Edipping fault planes.

The structure between the two lobes, similarly to the STEP fault system, may be driven by slab breakoff, tearing and plate fragmentation during the terminal stages of subduction. Low seismic penetration in the Messina Straits region does not allow us to understand whether this structure involves the basement. Correlation with the thick-skinned reverse faulting described in the outer wedge (Polonia et al., 2011) suggests that deformation may be deeply rooted also in this area and related to slab dynamics and mantle flow, i.e. the primary trigger of dynamic topography in Calabria and Sicily (Faccenna et al., 2011). A comparison between tectonic features in the Messina Straits, gravity anomaly profiles and tomography (Neri et al., 2012) suggests that this area is located on top of the southern edge of a high velocity anomaly related to the subducting slab. In this view, the Messina straits fault system could represent the shallow expression of mantle deformation around the SW side of the subducting slab. We underline that a similar situation is present in the Crotone basin located on the NE lateral boundary of the subducting slab, where the disruption and fragmentation of the Calabrian wedge has been reconstructed from paleomagnetic data and related to the partial breakoff of the Ionian slab after $1 \mathrm{Ma}$ (Speranza et al., 2012). Quaternary uplift and deformation in the Messina Straits region, as well as basaltic volcanism, may thus be seen as related to crustal-tearing between a still active southern Calabria and the western region (NE Sicily) located above an already detached Ionian slab. Recent seismicity in the Messina Straits area (Fig. 10) shows a cluster of earthquakes close to the proposed fault.

The proposed active faults, their inception, kinematics and sedimentary basin evolution are related to the regional geodynamics and the succession of major tectonic phases of the 


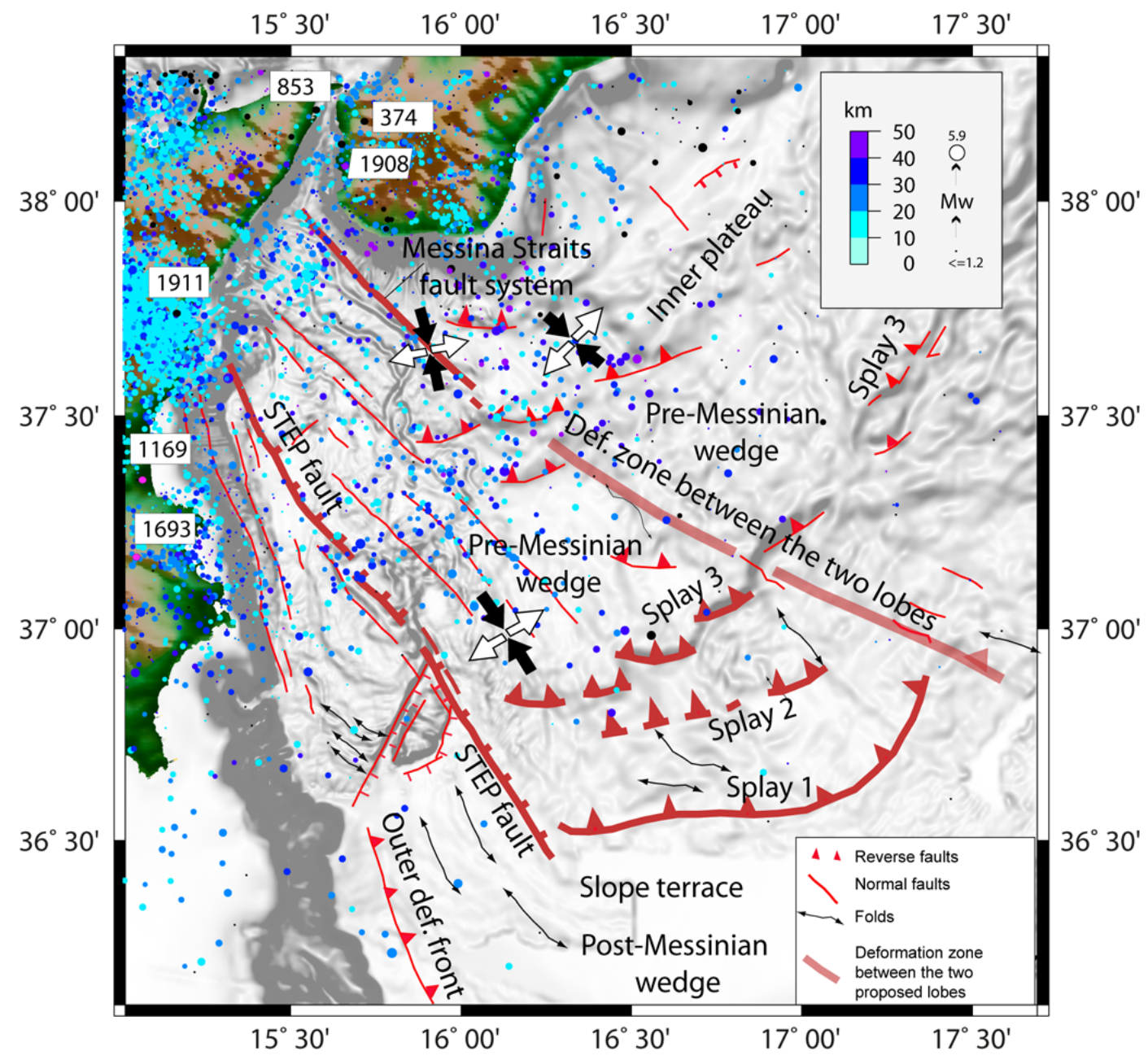

Fig. 10. Tectonic map of the western CA area with major seismogenetic structures indicated (STEP, Splay-1, -2, -3 , and Messina Straits fault systems). Filled circles mark earthquake epicenters in the region during the period 1981-2011 from two different catalogs: CSI1.1 (Castello et al., 2006) and ISIDe (ISIDe Working Group (INGV, 2010), Italian Seismological Instrumental and parametric database: http://iside.rm.ingv.it). Radius of the circles is proportional to estimated magnitude (from 1.2 to 5.9), while colours represent depth intervals (from 0 to $50 \mathrm{~km}$; black $>50 \mathrm{~km}$ ). The directions of maximum and minimum horizontal contractional strain rates described by Jenny et al. (2006) are represented in three key sites of the western CA (black and white arrows): they are in agreement with the proposed seismogenic fault systems.

Ionian subduction. During mid-late Pliocene, subduction of the Ionian slab intersected the narrow gap between Hyblean and Apulian continental blocks, producing a shortening acceleration (Steckler et al., 2010) that may be responsible for splay-fault inception. The following longitudinal expansion of the system due to a new rapid rollback of the Calabrian Arc resumed during Early Pleistocene and the present. Slab tearing processes accelerated and triggered mantle flow and dynamic topography in Calabria and NE Sicily (Faccenna et al., 2011). This may account for transtensional deformation in the inner portions of the subduction complex described both along the Malta STEP fault and Messina Straits fault systems and mass wasting at the toe of the Malta escarpment (MTD on top of the accretionary wedge in Fig. 6).

\subsection{Correlation with historical earthquakes}

Among the known major earthquakes (Table 1), the 1908, 1693 and 1169 events had magnitude and epicenter location that could support an offshore source, in agreement with their tsunamigenic nature. No definitive source model has been put forward for these earthquakes, and large uncertainties exist. Offshore causative faults are often considered unlikely mainly because of historical data, and also because submarine sources would require very large magnitude earthquakes to produce the observed on-land macroseismic reconstructions. This information, on the other hand, may be misleading especially for earthquakes that are clustered in seismic sequences, where macroseismic damage represents the summation of all the events occurred during the seismic 
sequence. Moreover, the very strong and unexpected 2004 Sumatra-Andaman $M_{\mathrm{w}}=9.1$ to 9.3 (Lay et al., 2005) and $2011 M_{\mathrm{w}}=9$ Tohoku-Oki earthquakes (Ozawa et al., 2011) suggest that probabilistic models used to define the "expected" earthquake in a region may underestimate the effective potential of seismogenic faults, at least along subduction zone megathrust plate boundaries. This may imply that also in the Mediterranean region the expected magnitudes may be higher than predicted by statistical models. Our results in the Ionian Sea provide location, length and geometry of faults that could be seismogenic, and they need to be taken into account for any reliable risk assessment.

Gravity cores collected in tectonically controlled sedimentary basins close to the described active faults show that the pelagic sequence of the Ionian Sea is interbedded with redeposited units that represent more than $80 \%$ of sedimentation. Radiometric ages of three recent turbidite sequences from two different cores suggest that turbidite emplacement was triggered by the 1908, 1693 and 1169 events (Polonia et al., 2012). These results confirm that these earthquakes triggered submarine landslides. The occurrence of a turbidite does not necessarily imply that the earthquake occurred at sea, but, combined with tsunami observations, it supports a submarine causative fault or a structure not far from the sea, capable to produce mass movements at the sea bottom where the susceptibility to mass failure is higher.

The strike of the proposed Messina Straits fault is not in agreement with source models of the 1908 earthquake that consider a NNE-SSW trending fault (Valensise and Pantosti, 1982; Monaco and Tortorici, 2000). On the other hand, other models such as those by Amoruso et al. (2002) and Capuano et al. (1988) suggest a causative fault striking $\mathrm{N}$ or N5W, closer to that described in this work. The main effect at the seafloor after the 1908 earthquake was subsidence affecting the entire Messina Straits, but was concentrated mainly in the southern part, where the Messina Strait is wider and opens to the Ionian Sea. Moreover, the lack of extensional faults within the Messina Straits supports interpretation of a seismogenic fault located south of this area. A causative fault located offshore southern Calabria was proposed by Galli et al. (2007) based on structural studies and arrival times of the 1908 tsunami on the Sicilian and Calabrian coasts (Tinti, 2007). Argnani et al. (2009b) described a fault scarp close to southern Calabria (their Fig. 9) but consider it unlikely that this low angle fault might create an earthquake with the macroseismic intensity observed along the Calabria coast; they propose that during the 1908 earthquake more than one fault may have been activated with their "southern Calabria fault", producing the tsunami wave.

Our reconstruction implies that immediately south of the Messina Straits, a steep east-dipping fault is present at depth and satisfies the requirements of the causative fault for the 1908 earthquake. The tsunami source region proposed by Billi et al. (2008), through the backward ray-tracing techniques, corresponds to the location of our proposed fault system.

The Messina Straits fault system, as deduced by our interpretation, is located along a pre-existing compressive fault that has been re-activated in transtension during recent times. This kinematics is similar to that reconstructed for the Malta STEP fault system, which suggests a regional geodynamic change in the Ionian Sea tectonics. In light of these results, the extension described within the Messina Straits (D'Agostino and Selvaggi, 2004) is compatible with our proposed fault system if a series of NW-SE right-stepping fault segments are present in the region.

A better knowledge of the geometry and kinematics of this fault system, as well as further modelling, should respond on whether its length, geometry and location are compatible with the reported 1908 coseismic surface deformation, seismological data and tsunami runup observations.

The Ambraseys-Sieberg intensity $\mathrm{V}$ tsunami related to the 1693 earthquake (Tinti et al., 2004) and the isoseismals opened to the sea suggest that the source region for this strong event may be located in the submerged portion of the CA subduction complex (Gutscher et al., 2006). Tsunami modelling of a subduction fault plane $(160 \times 120 \mathrm{~km})$ reproduced successfully available historical observations with regard to polarity and predicts 1-3 m amplitudes (Gutscher et al., 2006); this has been used to assume a locked subduction fault plane in the CA that may have ruptured in 1693. We propose that the Malta STEP fault system, together with splay faults, may have generated such a strong earthquake as well as the 1169 earthquake.

The length of active faults may be used to predict the magnitude of the expected earthquake (Wells and Coppersmith, 1994), although the uncertainties are very high; assuming that (i) active faults are not segmented along their length, at least at depth, and (ii) single fault ruptures affect the entire fault length, the maximum expected moment magnitude $(M)$ for earthquakes occurring on the Malta STEP fault (length $120,150 \mathrm{~km}$ ) is about 7.4-7.6; $M$ for earthquakes occurring on the splay fault systems ranges from 7.2 (Splay-2) to 7.4 (Splay-1) and 7.6 for Splay-3 in the EL offshore Calabria (length of approximately $150 \mathrm{~km}$ ). This $M$ is associated with a maximum displacement along the Splay-3 fault system of about $2 \mathrm{~m}$. Considering that the convergence rate reported by GPS is between 2 and $4 \mathrm{~mm} \mathrm{a}^{-1}$ (D'Agostino et al., 2008; Devoti et al., 2008), the first approximation of recurrence time of such earthquakes is about 500-1000 a.

Uncertainties are larger for the Messina Straits fault system, as we have not enough data to map its SE termination and the transition from the relatively narrow fault zone of Fig. 9 to the more diffuse area of deformation between the two lobes of the accretionary wedge. If the $M_{\mathrm{w}}=7.24$ 1908 event was generated by this fault, surface rupture length should be about $80 \mathrm{~km}$, as deduced using Wells and Coppersmith (1994) relationships. This is compatible with our findings. 
A multidisciplinary approach taking into account present plate motion, temperature conditions at the plate boundary, local seismicity, fault activity during the last thousand years and further modelling with the source parameters proposed in this work may help understand whether the newly proposed fault location, geometry and dip are compatible with known past earthquakes, particularly those considered in this work (1908, 1693 and 1169).

\section{Conclusions}

We analysed three tectonic features in the submerged portion of the Calabrian Arc that have the potential of generating major earthquakes in the region: (i) the Malta STEP fault system; (ii) a system of out-of-sequence thrust faults (splay faults) at the rear of the salt-bearing Messinian accretionary wedge; (iii) the Messina Straits fault system, part of the wide deformation zone separating the western and eastern lobes of the accretionary wedge.

Tectonic features described in this work are all first order structural elements directly ascribed to regional African/Eurasian plate convergence, slab break-off, tearing and recent plate-boundary re-organization. Fault inception and kinematics are related to the succession of major tectonic phases of the Ionian subduction system. Splay faults may have activated during the mid-late Pliocene shortening acceleration, which occurred when the Ionian slab intersected the narrow gap between Hyblean and Apulian continental blocks. The following rapid rollback of the Calabrian Arc and the longitudinal expansion of the system, which resumed during Early Pleistocene, may account for mantle flow, dynamic topography and transtensional deformation in the inner portions of the subduction complex described both along the Malta STEP fault and Messina Straits fault systems. This last structure, in particular, accommodates differential movements of the Calabrian and the Peloritan portions of the CA and might account for the NW-SE extension observed in the Messina straits, as well as the relative motion between Calabria and NE Sicily.

Integrated analysis of location, geometry and kinematics of tectonic features, as well as correlation with the catalogue of historical earthquakes, has been carried out in order to define causal relationships between the proposed seismogenic features and specific seismic events in the area. We propose that the 1908 earthquake may have been triggered by the Messina Straits fault system, while the 1693 and 1169 earthquakes, for which little information is available, may be related to the Malta STEP fault and/or the splay fault systems. Source parameters derived by this study can be used to reconsider location of historical earthquakes, particularly those lacking clear reports.

Finally, tsunami scenarios should be evaluated at the scale of the entire Mediterranean Basin, because large far-field sources may produce higher tsunami waves than smaller local sources. Accordingly, the proposed active faults in the CA subduction complex have to be taken into account also for the tsunami hazard facing the entire Mediterranean Sea. We further stress that a multidisciplinary/multiscale approach that involves the fine scale reconstruction of single fault strand dynamics with the study of regional tectonics, paleoceanography, stratigraphy and ultimately basin evolution is needed in any submarine paleoseismological study.

Acknowledgements. The CALAMARE scientific party (G. Bortoluzzi, C. Carmisciano, G. Carrara, M. Cuffaro, F. D’Oriano, M. Gambetta, M. Ligi, X. Locritani, L. Minelli, F. Muccino, D. Oppo, F. Riminucci, I. Viola), Captain Lubrano, Urania shipboard and SOPROMAR parties are greatly acknowledged for the contribute in data acquisition during the Urania cruise. We greatly acknowledge the CIESM/Ifremer Medimap group (B. Loubrieu et al., 2008) for having provided us with the multibeam grid of the study area. Most maps were generated using the GMT software (Wessel and Smith, 1991), while structural mapping has been performed with the SeisPrho software (Gasperini and Stanghellini, 2009). We thank D. Klaeschen for assistance in seismic data processing and P. Gasperini, E. Ercolani and E. Bonatti for useful discussions. We are greatly indebted with this Special Edition Guest Editor Geoffroy Lamarche as well as A. Billi, A. Camerlenghi and an anonymous reviewer for very constructive comments. This work has been supported by ESF-TOPOMED (Plate re-organization in the western Mediterranean: Lithospheric causes and topographic consequences) project. ISMAR paper n. 1754 .

Edited by: G. Lamarche

Reviewed by: A. Billi, A. Camerlenghi, and another

anonymous referee

\section{References}

Amoruso, A., Crescentini, L., and Scarpa, R.: Source parameters of the 1908 Messina Straits, Italy, earthquake from geodetic and seismic data, J. Geophys. Res., 107, 2080, doi:10.1029/2001JB000434, 2002.

Argnani, A. and Bonazzi C.: Malta Escarpment fault zone offshore eastern Sicily: Plio-Quaternary tectonic evolution based on new multi-channel seismic data, Tectonics, 24, TC4009, doi:4010.1029/2004TC001656, 2005.

Argnani, A., Chiocci, F. L., Tinti, S., Bosman, A., Lodi, M. L., Pagnoni, G., and Zaniboni, F.: Comment on "On the cause of the 1908 Messina tsunami, southern Italy" by Andrea Billi et al., Geophys. Res. Lett., 36, L13307, doi:10.1029/2009GL037332, 2009a.

Argnani, A., Brancolini, G., Bonazzi, C., Rovere, M., Accaino, F., Zgur, F., and Lodolo E.: The results of the Taormina 2006 seismic survey: Possible implications for active tectonics in the Messina Straits, Tectonophysics, 476, 159-169, doi:10.1016/j.tecto.2008.10.029, 2009b.

Baratta, M.: La Catastrofe Sismica Calabro-Messinese (28 Dicembre 1908), Soc. Geogr. Ital., Rome, 496 pp., 1910.

Bianca, M., Monaco, C., Tortrici, L., and Cernobori, L.: Quaternary normal faulting in southeastern Sicily (Italy): A seismic source 
for the 1693 large earthquake, Geophys. J. Int., 139, 370-394, 1999.

Bilich, A., Frohlich, C., and Mann, P.: Global seismicity characteristics of subduction-to-strike-slip transitions, J. Geophys. Res., 106, 19443-19452, 2001.

Billi, A., Barberi, G., Faccenna, C., Neri, G., Pepe, F., and Sulli, A.: Tectonics and seismicity of the Tindari Fault System, southern Italy: Crustal deformation at the transition between ongoing contractional and extensional domains located above the edge of a subducting slab, Tectonics, 25, TC2006, doi:2010.1029/2004TC001763, 2006.

Billi, A., Presti, D., Faccenna, C., Neri, N., and Orecchio, B.: Seismotectonics of the Nubia plate compressive margin in the south Tyrrhenian region, Italy: Clues for subduction inception, J. Geophys. Res., 112, B08302, doi:10.1029/2006JB004837, 2007.

Billi, A., Funiciello, R., Minelli, L., Faccenna, C., Neri, G., Orecchio, B., and Presti, D.: On the cause of the 1908 Messina tsunami, southern Italy, Geophys. Res. Lett., 35, L06301, doi:10.1029/2008GL033251, 2008.

Billi, A., Minelli, L., Orecchio, B., and Presti, D.: Runup Distribution for the 1908 Messina Tsunami in Italy: Observed Data versus Expected Curves, Bull. Seism. Soc. Am., 99, 3502-3509, doi:10.1785/0120090128, 2009.

Billi, A., Minelli, L., Orecchio, B., and Presti, D.: Constraints to the Cause of Three Historical Tsunamis (1908, 1783, and 1693) in the Messina Straits Region, Sicily, Southern Italy, Seismol. Res. Lett., 81, 907-915, 2010.

Boschi, E., Guidoboni, E., Ferrari, G., Valensise, G., and Gasperini, P. (Eds.): Catalogo dei forti terremoti in Italia dal 461 a.C. al 1980, 2, ING-SGA, Bologna, 644 pp., 1997.

Bottari, A., Carapezza, E., Carapezza, M., Carveni, P., Cefali, F., Lo Giudice, E., and Pandolfo, C.: The 1908 Messina Strait earthquake in the regional geostructural framework, J. Geodynam., 5, 275-302, doi:10.1016/0264-3707(86)90010-4, 1986.

Bottari, A., Capuano, P., De Natale, G., Gasparini, P., Neri, G., Pingue, F., and Scarpa, R.: Source parameters of earthquakes in the Strait of Messina, Italy, during this century, Tectonophysics, 166, 221-234, 1989.

Calais E., DeMets, C., and Nocquet, J. M.: Evidence for a post3.16 Ma change in Nubia-Eurasia-North America plate motions?, Earth Planet. Sc. Lett., 216, 81-92, 2003.

Capuano, P., De Natale, G., Gasparini, P., Pingue, F., and Scarpa, R.: A model for the 1908 Messina Straits (Italy) earthquake by inversion of levelling data, Bull. Seismol. Soc. Am., 78, 19301947, 1988.

Castello, B., Selvaggi, G., Chiarabba, C., and Amato, A.: CSI, Catalogo della sismicità italiana 1981-2002, versione 1.1. INGVCNT, Roma, available at: http://csi.rm.ingv.it/ (last access: 15 March 2012), 2006.

Cernobori, L., Hirn, A. McBride, J. H., Nicolich, R., Petronio, L., and Romanelli, M.: STREAMERS/PROFILES Working Groups: Crustal image of the Ionian basin and its Calabrian margins, Tectonophysics, 264, 175-189, 1996.

Chamot-Rooke, N., Rangin, C., Le Pichon, X., and DOTMED Working Group: DOTMED - Deep Offshore Tectonics of the Mediterranean: A synthesis of deep marine data in eastern Mediterranean, Mem. S. Geo. F. \& AAPG, special number, 177, 64 pp., 69 maps with cd-rom, 2005.
CPTI Working Group: Catalogo Parametrico dei Terremoti Italiani. Istituto Nazionale di Geofisica, Gruppo Nazionale per la Difesa dai Terremoti, Storia Geofisica Ambiente, Servizio Sismico Nazionale, Bologna, 2004.

D'Agostino, N. and Selvaggi, G.: Crustal motion along the EurasiaNubia plate boundary in the Calabrian Arc and Sicily and active extension in the Messina Straits from GPS measurements, J. Geophys. Res., 109, B11402, doi:10.1029/2004JB002998, 2004.

D’Agostino, N., Avallone, A., Cheloni, D., D'Anastasio, E., Mantenuto, S., and Selvaggi, G.: Active tectonics of the Adriatic region from GPS and earthquake slip vectors, J. Geophys. Res., 113, B12413, doi:12410.11029/12008JB005860, 2008.

DeCelles, P. G. and Cavazza, W.: Upper Messinian conglomerates in Calabria, southern Italy: Response to orogenic wedge adjustment following Mediterranean sea-level changes, Geology, 23, 775-778, 1995.

De Natale, G. and Pingue, F.: A variable slip fault model for the 1908 Messina Straits (Italy) earthquake, by inversion of levelling data, Geophys. J. Int., 104, 73-84, 1991.

Devoti, R., Riguzzi, F., Cuffaro, M., and Doglioni, C.: New GPS constraints on the kinematics of the Apennines subduction, Earth Planet. Sc. Lett., 273, 163-174, 2008.

Doglioni, C., Merlini, S., and Cantarella, G.: Foredeep geometries at the front of the Apennines in the Ionian Sea (central Mediterranean), Earth Planet. Sc. Lett., 168, 243-254, 1999.

Doglioni, C., Innocenti, F., and Mariotti, G.: Why Mt Etna?, Terra Nova, 13, 25-31, 2001.

Faccenna, C., Molin, P., Orecchio, B., Olivetti, V., Bellier, O., Funiciello, F., Minelli, L., Piromallo, C., and Billi, A.: Topography of the Calabria subduction zone (southern Italy): Clues for the origin of Mt. Etna, Tectonics, 30, TC1003, doi:10.1029/2010TC002694, 2011.

Favalli, M., Boschi, E., Mazzarini, F., and Pareschi, M. T.: Seismic and landslide source of the 1908 Straits of Messina tsunami (Sicily, Italy), Geophys. Res. Lett., 36, L16304, doi:10.1029/2009GL039135, 2009.

Finetti, I.: Structure, stratigraphy and evolution of Central Mediterranean, B. Geofis. Teor. Appl., XXIV, 247-312, 1982.

Galli, P. and Bosi, V.: Catastrophic 1638 earthquakes in Calabria (southern Italy): New insights from paleoseismological investigation, J. Geophys. Res., 108, 2004, doi:10.1029/2001JB001713, 2003.

Galli, P., Scionti, V., and Spina, V.: New paleoseismic data from the Lakes and Serre faults: seismotectonic implications for Calabria (Southern Italy), Boll. Soc. Geol. It. 126, 347-364, 2007.

Gasperini, L. and Stanghellini, G.: SeisPrho: An interactive computer program for processing and interpretation of highresolution seismic reflection profiles, Comput. Geosci., 35, 1497-1507, 2009.

Goes, S., Giardini, D., Jenny, S., Hollenstein, C., Kahle, H.-G., and Geiger, A.: A recent tectonic reorganization in the south-central Mediterranean, Earth Planet. Sc. Lett., 226, 335-345, 2004.

Govers, R. and Wortel, M. J. R.: Lithosphere tearing at STEP faults: Response to edges of subduction zones, Earth Planet. Sc. Lett., 236, 505-523, 2005.

Gulick, S. P. S., Austin Jr., J. A., McNeill, L. C., Bangs, N. L. B., Martin, K. M., Henstock, T. J., Bull, J. M., Dean, S., Djajadihardja, Y. S., and Permana, H.: Updip rupture of the 2004 Sumatra earthquake extended by thick indurated sediments, Nat. 
Geosci., 4, 453-456, doi:10.1038/ngeo1176, 2011.

Gutscher, M.-A., Roger, J., Baptista, M.-A., Miranda, J. M., and Tinti, S.: Source of the 1963 Catania earthquake and tsunami (southern Italy): New evidence from tsunami modelling of a locked subduction fault plane, Geophys. Res. Lett., 33, L08309, doi:08310.01029/02005GL025442, 2006.

Ichinose, G., Somerville, P., Thio, H. K., Graves, R., and O'Connell, D.: Rupture process of the 1964 PrinceWilliam Sound, Alaska, earthquake from the combined inversion of seismic, tsunami, and geodetic data, J. Geophys. Res., 112, B07306, doi:10.1029/2006JB004728, 2007.

Jacques, E., Monaco, C., Tapponnier, P., Tortorici, L., and Winter, T.: Faulting and earthquake triggering during the 1783 Calabria seismic sequence, Geophys. J. Int., 147, 1-25, 2001.

Jenny, S., Goes, S., Giardini, D., and Kahle, H.-G.: Seismic potential of Southern Italy, Tectonophysics, 415, 81-101, 2006.

Kimura, G., Screaton, E. J., and Curewitz, D.: NanTroSEIZE Stage 1: NanTROSEIZE shallow megasplay and frontal thrusts, IODP Sci. Prosp., 316, doi:10.2204/iodp.sp.316, 2007.

Kimura, G., Moore, G. F., Strasser, M., Screaton, E., Curewitz, D., Streiff, C., and Tobin, H.: Spatial and temporal evolution of the megasplay fault in the Nankai Trough, Geochem. Geophy. Geosy., 12, Q0A008, doi:10.1029/2010GC003335, 2011.

Lay, T., Kanamori, H., Ammon, C. J., Nettles, M., Ward, S. N., Aster, R. C., Beck, S. L., Bilek, S. L., Brudzinski, M. R., Butler, R., Deshon, H. R., Ekstrom, G., Satake, K., and Sipkin, S.: The great Sumatra-Andaman earthquake of 26 December 2004, Science, 308, 1127-1132, 2005.

Loperfido, A.: Livellazione geometrica di precisione eseguita dall'IGMI sulla costa orientale della Sicilia, da Messina a Catania, a Gesso ed a Faro Peloro e sulla costa occidentale della Calabria da Gioia Tauro a melito di Porto salvo, C.R. Accademia Naz. Lincei, 35, 131-155, 1909.

Loubrieu, B., Mascle, J., and MediMap Group: MorphoBathymetry of the Mediterranean Sea, In Special Publication, 1/3.000000 scale map., CIESM, 1-2, 2008.

Minelli, L. and Faccenna, C.: Evolution of the Calabrian Accretionary wedge (Central Mediterranean), Tectonics, 29, TC4004, doi:10.1029/2009TC002562, 2010.

Monaco, C. and Tortorici, L.: Active faulting in the Calabrian arc and eastern Sicily, J. Geodynam., 29, 407-424, doi:10.1016/S0264-3707(99)00052-6, 2000.

Moore, G. F., Bangs, N. L., Taira, A., Kuramoto, S., Pangborn, E., and Tobin, H. J.: Three-Dimensional Splay Fault Geometry and Implications for Tsunami Generation, Science, 318, 5853, 11281131, doi:10.1126/science.1147195, 2007.

Mulargia, F. and Boschi, E.: The 1908 Messina earthquake and related seismicity, in Earthquakes: observation, theory and interpretation, edited by: Kanamori, H. and Boschi, E., Proc. Int. Sch. Phys. Enrico Fermi, Course LXXXV, 493-518, 1983.

Neri, G., Orecchio, B., Totaro, C., Falcone, G., and Presti, D.: Subduction Beneath Southern Italy Close the Ending: Results from Seismic Tomography, Seismol. Res. Lett., 80, 63-70, 2009.

Neri, G., Marotta, A. M., Orecchio, B., Presti, D., Totano, C., Barzaghi, R., and Borghi, A.: How lithospheric subduction changes along the Calabrian Arc in southern Italy: geophysical evidences, Int. J. Earth Sci., online first, doi:10.1007/s00531-012-0762-7, 2012.
Okal, E. A. and Synolakis, C. E.: Source discriminants for nearfield tsunamis, Geophys. J. Int., 158, 899-912, 2004.

Omori, F.: Preliminary report on the Messina-Reggio Earthquake of Dec. 28, 1908, Bulletin of Imperial Earthquake Investigation Committee, 3, 37-46, 1909.

Ozawa, S., Nishimura, T., Suito, H., Kobayashi, T., Tobita, M., and Imakiire, T.: Coseismic and postseismic slip of the 2011 magnitude-9 Tohoku-Oki earthquake, Nature, 475, 373-376, doi:10.1038/nature10227, 2011.

Panieri, G., Polonia, A., Zironi, S. Lucchi, R. G., Capotondi, L., Negri, A., and Torelli, L.: Evidence of mud diapirism along the inner deformation front of the Calabrian Arc accretionary wedge (Ionian Sea), accepted, Mar. Geol., 2012.

Park, J.-O., Tsuru, T., Kodaira, S., Cummins, P. R., and Kaneda Y.: Splay fault branching along the Nankai subduction zone, Science, 297, 1157-1160, 2002.

Piatanesi, A. and Tinti, S.: A revision of the 1693 eastern Sicily earthquake and tsunami, J. Geophys. Res., 103, 2749-2758, 1998.

Pino, N. A., Piatanesi, A., Valensise, G., and Boschi, E.: The 28 December 1908 Messina Straits earthquake (Mw 7.1): a great earthquake throughout a century of seismology, Seismol. Res. Lett., 80, 243-259, 2009.

Platania, G.: Il maremoto dello Stretto di Messina del 28 Dicembre 1908, Boll. Soc. Sism. It., 22, 369-458, 1909.

Polonia, A., Torelli, L., Mussoni, P., Gasperini, L., Artoni, A., and Klaeschen, D. The Calabrian Arc subduction complex in the Ionian Sea: Regional architecture, active deformation, and seismic hazard, Tectonics, 30, TC5018, doi:10.1029/2010TC002821, 2011.

Polonia, A., Panieri, G., Gasperini, L., Gasparotto, G., Zironi, S., and Torelli, L.: Historical earthqaukes and turbidites in the Calabrian Arc subduction complex, Earth Planet Sc. Lett., submitted, 2012.

Praeg, D., Ceramicola, S., Barbieri, R., Unnithan, V., and Wardell, N.: Tectonically-driven mud volcanism since the late Pliocene on the Calabrian accretionary prism, Central Mediterranean Sea, Mar. Petrol. Geol., 26, 1849-1865, doi:1810.1016/j.marpetgeo.2009.1803.1008, 2009.

Reilinger, R., McClusky, S., Vernant, P., Lawrence, S., Ergintav, S., Cakmak, R., Ozener, H., Kadirov, F., Guliev, I., Stepanyan, R., Nadariya, M., Hahubia, G., Mahmoud, S., Sakr, K., ArRajehi, A., Paradissis, D., Al-Aydrus, A., Prilepin, M., Guseva, T., Evren, E., Dmitrotsa, A., Filikov, S. V., Gomez, F., Al-Ghazzi, R., and Karam, G.: GPS constraints on continental deformation in the Africa-Arabia-Eurasia continental collision zone and implications for the dynamics of plate interactions, J. Geophys. Res., 111, B05411, doi:05410.01029/02005JB004051, 2006.

Rosenbaum, G., Gasparon, M., Lucente, F. P., Peccerillo, A., and Miller, M. S.: Kinematics of slab tear faults during subduction segmentation and implications for Italian magmatism, Tectonics, 27, TC2008, doi:10.1029/2007TC002143, 2008.

Rossi, S. and Sartori, R.: A seismic reflection study of the external Calabrian arc in the northern Ionian Sea (Eastern Mediterranean), Mar. Geophys. Res., 4, 403-426, 1981.

Ryan, W. B. F. and Heezen, B. C.: Ionian Sea submarine canyons and the 1908 Messina turbidity current, Geol. Soc. Am. Bull., 76, 915-932, 1965. 
Schick, R.: Eine seismotektonische Bearbeitung des Erdbebens von Messina im Jahre 1908, Geol. Jb., 11, 3-74, 1977.

Selvaggi, G. and Chiarabba, C.: Seismicity and P-Wave Velocity Image of the Southern Tyrrhenian Subduction Zone, Geophys. J. Int., 121, 818-826, 1995.

Serpelloni, E., Vannucci, G., Pondrelli, S., Argnani, A., Casula, G., Anzidei, M., Baldi, P., and Gasperini, P.: Kinematics of the Western Africa-Eurasia plate boundary from focal mechanisms and GPS data, Geophys. J. Int., 169, 1180-1200, 2007.

Shaw, B., Ambraseys, N. N., England, P. C., Floyd, M. A., Gorman, G. J., Higham, T. F. G., Jackson, J. A., Nocquet, J.-M., Pain C. C., and Piggott, M. D.: Eastern Mediterranean tectonics and tsunami hazard inferred from the AD 365 earthquake, Nat. Geosci., 1, 268-276, doi:10.1038/ngeo151, 2008.

Sirovich, L. and Pettenati, F.: Seismotectonic outline of SouthEastern Sicily: an evaluation of available options for the scenario earthquake fault rupture, J. Seismol., 3, 213-233, 1999.

Speranza, F., Macrì, P., Rio, D., Fornaciari, E., and Consolaro, C.: Paleomagnetic evidence for a post-1.2 Ma disruption of the Calabria terrane: Consequences of slab breackoff on orogenic wedge tectonics, GSA Bulletin, 123, 925-933, doi:10.1130/B30214.1, 2012.

Steckler, M. S., Baccheschi, P., Cardinali, M., Dewez, T., Faccenna, C., Finkel, R. C., Gervasi, A., Guerra, I., Guzzetti, F., Huot, S., Kim, W., Lamothe, M., Lavier, L. L., Malinverno, A., Margheriti, L., Nedimovic, M. R., Agostinetti, N. P., Reitz, M. A., Seeber, L., Stark, C. P., Schaefer, J. M., and Thomson, S. N.: Tectonics at the Transition from Subduction to Collision at the Calabrian Arc, AGU Fall meeting, Session T13G - The Formation and Deformation of the Mediterranean Basins, Continental Margins, and Arcs I, \# T31G-07, 13-17 December 2010, San Francisco, CA, USA, (Abstract, Oral), 2010.

Tappin, D. R.: The 1908 Messina tsunami, Some comments on the source: Earthquake, subamrine landslide or a combination of both?, Eos Trans. AGU, 89, Fall Meet. Suppl., Abstract S41D07, 2008.
Tinti, S.: I maremoti delle coste italiane, Geoitalia, 19, 4-10, 2007. Tinti, S. and Giuliani, D.: The Messina Straits Tsunami of December 28, 1908: a critical review of experimental data and observation, Il Nuovo Cimento, 6, 429-442, 1983.

Tinti, S., Maramai, A., and Graziani, L.: The new catalogue of the Italian tsunamis, Nat. Hazards, 33, 439-465, 2004.

Tinti, S., Armigliato, A., Zaniboni, F., Tonini, R., Pagnoni, G., Gallazzi, S., Manucci, A., and Pontrelli P.: Quale sorgente per il maremoto del 28 Dicembre 1908 nello Stretto di Messina? Terremoto, frana sottomarina o entrambe?, in $27^{\circ}$ Convegno Nazionale, Gruppo Naz. di Geofis. Della Terra Solida, Trieste, Italy, 191-192, 2008.

Tobin, H. J. and Kinoshita, M.: Investigations of seismogenesis at the Nankai Trough, Japan, IODP Sci. Prosp., NanTroSEIZE Stage, 1, 1-30, doi:10.2204/iodp.sp.nantroseize1.2006, 2006.

Tonini, R., Armigliato, A., Pagnoni, G., Zaniboni, F., and Tinti, S.: Tsunami hazard for the city of Catania, eastern Sicily, Italy, assessed by means of Worst-case Credible Tsunami Scenario Analysis (WCTSA), Nat. Hazards Earth Syst. Sci., 11, 1217-1232, doi:10.5194/nhess-11-1217-2011, 2011.

Valensise, G. and Pantosti, D.: A 125-Kyr-long geological record of seismic source repeatability: the Messina Straits (southern Italy) and the 1908 earthquake (MS 71), Terra Nova, 4, 472-483, 1982.

Wells, D. L. and Coppersmith, K. J.: New Empirical Relationships among Magnitude, Rupture Length, Rupture width, Rupture Area, and Surface Displacement, B. Seismol. Soc. Am., 84, 974-1002, 1994.

Wessel, P. and Smith, W. H. F.: Free software helps map and display data, EOS, Transactions - American Geophysical Union, 72, 445-446, 1991.

Wortel, M. J. R. and Spakman, W.: Subduction and Slab Detachment in the Mediterranean-Carpathian Region, Science, 290, 1910-1917, 2000. 